Review

\title{
Neurodegenerative Diseases: Might Citrus Flavonoids Play a Protective Role?
}

\author{
Santa Cirmi ${ }^{1}$, Nadia Ferlazzo ${ }^{1}$, Giovanni E. Lombardo ${ }^{2}$, Elvira Ventura-Spagnolo ${ }^{3}$, \\ Sebastiano Gangemi ${ }^{4,5}$, Gioacchino Calapai ${ }^{6}$ and Michele Navarra ${ }^{1, *}$ \\ 1 Department of Chemical, Biological, Pharmaceutical and Environmental Sciences, University of Messina, \\ viale Annunziata, Messina I-98168, Italy; scirmi@unime.it (S.C.); nadiaferlazzo@email.it (N.F.) \\ 2 Department of Health Sciences, University “Magna Graecia” of Catanzaro, Catanzaro I-88100, Italy; \\ gelombardo@unicz.it \\ 3 Department of Biotechnology and Legal Medicine, University of Palermo, Palermo I-90127, Italy; \\ elvira.ventura@unipa.it \\ 4 Department of Clinical and Experimental Medicine, University of Messina, Messina I-98125, Italy; \\ gangemis@unime.it \\ 5 Institute of Applied Sciences and Intelligent Systems (ISASI), National Research Council (CNR), \\ Pozzuoli I-80078, Italy \\ 6 Department of Biomedical and Dental Sciences and Morphofunctional Imaging, University of Messina, \\ Messina I-98125, Italy; gcalapai@unime.it \\ * Correspondence: mnavarra@unime.it; Tel.: +39-090-676-6431
}

Academic Editor: Luigia Trabace

Received: 29 July 2016; Accepted: 14 September 2016; Published: 30 September 2016

\begin{abstract}
Neurodegenerative diseases (ND) result from the gradual and progressive degeneration of the structure and function of the central nervous system or the peripheral nervous system or both. They are characterized by deterioration of neurons and/or myelin sheath, disruption of sensory information transmission and loss of movement control. There is no effective treatment for ND, and the drugs currently marketed are symptom-oriented, albeit with several side effects. Within the past decades, several natural remedies have gained attention as potential neuroprotective drugs. Moreover, an increasing number of studies have suggested that dietary intake of vegetables and fruits can prevent or delay the onset of ND. These properties are mainly due to the presence of polyphenols, an important group of phytochemicals that are abundantly present in fruits, vegetables, cereals and beverages. The main class of polyphenols is flavonoids, abundant in Citrus fruits. Our review is an overview on the scientific literature concerning the neuroprotective effects of the Citrus flavonoids in the prevention or treatment of ND. This review may be used as scientific basis for the development of nutraceuticals, food supplements or complementary and alternative drugs to maintain and improve the neurophysiological status.
\end{abstract}

Keywords: Citrus; flavonoids; neurodegeneration; neurodegenerative disorders; nutraceutical

\section{Introduction}

The increase of the lifespan in populations of developed countries is leading to a rise in the incidence of age-related illnesses such as neurodegenerative diseases (ND). ND are a heterogeneous group of chronic and untreatable conditions that, in terms of human suffering and economic cost for society, represent the fourth highest source of overall disease burden in high-income countries. ND result from the gradual and progressive degeneration of the structure and function of both the central nervous system (CNS) and the peripheral nervous system (PNS), characterized by deterioration of neurons and/or myelin sheath, sensory information transmission disruption and movement control. 
It is known that oxidative stress and chronic inflammation play an important role in ND. Free radicals represent a common denominator of many oxidative-based diseases, including ND, although they are normally and continuously produced in CNS, acting as important cellular messenger. However, excessive levels of reactive oxygen species (ROS) or reactive nitrogen species (RNS) are involved in numerous neuroinflammatory processes. In physiological conditions, the levels of free radicals are tightly regulated by a complex antioxidant defense system including both enzymatic and non-enzymatic antioxidants. Disruption of the delicate oxidant/antioxidant balance between the production and removal of oxidizing chemical species can lead to oxidative stress triggering cell damage. This may be due to an excessive production of ROS and RNS and/or at a reduced efficiency of the physiological antioxidant defense systems. Moreover, because of their high metabolic activities and low antioxidant defense capability, neural cells in brains are more vulnerable to oxidative stress, especially those of the aging brain. Furthermore, cytokines released by the activated glial cells amplify the free radicals-induced damage responsible for uncontrolled proteolysis, DNA mutagenesis, lipid peroxidation and cell death.

Currently there is no effective treatment for ND, and the marketed drugs are mainly symptom-oriented, albeit with many side effects, limited efficacy and partial capability to inhibit disease progression. Therefore, in order to develop novel preventive strategies or co-adjuvant therapy for ND, within the past decades, a great number of natural medicinal plants has gained attention as potential neuroprotective agents [1]. Moreover, an increasing number of studies have suggested that dietary intake of vegetables and fruits can prevent or delay the onset of ND [2,3]. These properties might be due to the presence of polyphenols, an important group of phytochemicals that are abundantly present in fruits, vegetables, cereals and beverages [4]. The main class of polyphenols is flavonoids which display a remarkable spectrum of biological activities, including antioxidant, free radical scavenger, metal ions chelating, vasoprotective, hepatoprotective, anti-inflammatory, anti-cancer and anti-infective [5,6]. Main dietary sources of flavonoids are fruits, especially Citrus fruits, vegetables, fruit juices, tea, coffee, and red wine [7]. Several lines of evidence have demonstrated the beneficial effects of Citrus fruits in the context of numerous pathologies, including ND, inflammation, cardiovascular diseases, dyslipidemia, diabetes, allergy, immune system diseases and cancer [8-24].

Our review is an overview on the scientific literature concerning the neuroprotective effects of the Citrus flavonoids in the prevention or treatment of ND.

\section{Focus on Neurodegenerative Disorders}

ND are incurable conditions due to the progressive nervous system dysfunction caused by degeneration and loss of nerve cells for reasons that have not yet been fully understood. Today, a growing number of people worldwide are affected by ND, characterized by deterioration in emotional control, social behavior and social communication. ND exist in many forms, such as Multiple Sclerosis, Alzheimer's, Parkinson's, Huntington's, human prion and motoneuron diseases.

Alzheimer's disease (AD) is a debilitating ND classified as the major subtype of dementia [25], and is characterized by progressive loss of memory. It results in decline in cognitive and behavioral functions like memory, thinking and language skills [26]. The hallmarks of AD are (i) the accumulation of amyloid-beta (A $\beta$ ) peptide in the brain; (ii) the presence of neurofibrillary tangles (NFTs) containing hyper-phosphorylated tau fragments and (iii) the loss of cortical neurons and synapses [27,28]. It is also known that the innate immune system activation plays a relevant role in the age-related ND, including AD. Microglia are innate immune cells in the CNS that mediate inflammatory responses to injury and pathogens by releasing pro-inflammatory cytokines that amplify and aggravate inflammation throughout the brain. These pro-inflammatory factors may induce degeneration of normal neurons through upregulation of nuclear factor kappa B (NF-kB), mitogen-activated protein kinase (MAPK), and c-Jun N-terminal kinase (JNK) [29].

Parkinson's disease (PD) is the second common neurodegenerative disorder and its incidence is increasing among people over the age of 60 years [30]. It is consistently higher in men than in 
women [31]. Pathologically, it is characterized by the progressive and diffuse loss of dopaminergic neurons in the substantia nigra and the accumulation of Lewy bodies (inclusions containing $\alpha$-synuclein) in nerve cells. The major clinical symptoms are tremor at rest, rigidity, bradykinesia and postural instability. It has been suggested that activated microglia may be beneficial to the host in the early phase of neurodegeneration but excessive activation of microglia leads to the elevated expression of pro-inflammatory mediators such as tumor necrosis factor alpha (TNF- $\alpha$ ), interleukin 1 beta (IL-1 $\beta$ ), interleukin-6 (IL-6) and interferon gamma (IFN- $\gamma$ ) [32], that induce the degeneration of substantia nigra pars compacta dopaminergic neurons [29,33]. Furthermore, the release of these pro-inflammatory mediators can activate astrocytes that participate to the neuroinflammatory processes linked to PD [34].

Huntington's disease (HD) is a hereditary neurological disorder inherited as an autosomal dominant trait [35] caused by an expanded polyglutamine tract in the N-terminal region of mutant huntingtin [36]. HD usually occurs in early middle life even if there is an uncommon juvenile form [37]. It is an illness that recurs with abnormal movements together with psychiatric symptoms including psychosis, depression, and obsessive-compulsive disorder and progressive cognitive impairment [38-40]. In the early stage of disease, neuronal loss occur preferentially in the striatum, while in the later stages the extensive neurodegeneration happens in a variety of brain regions [36,41].

Human prion diseases are fatal neurodegenerative disorders which include Kuru, Creutzfeldt-Jakob disease, Gerstmann-Sträussler-Scheinker syndrome, and fatal familial insomnia [42]. Prion diseases result from the conformational conversion of a normal cellular prion protein $(\operatorname{PrPC})$ into an abnormal misfolded pathological form $\left(\mathrm{PrP}^{\mathrm{Sc}}\right)$. Its accumulation in the CNS resulted in progressive neuronal degeneration and vacuolation [43].

Motor neuron disease (MND) is a neurodegenerative condition, among which the most common is the amyotrophic lateral sclerosis (ALS). MND affects both brain and spinal cord, and is due to the degeneration of motor neurons, that in turn causes muscle weakness. The major clinical symptoms include muscle weakness, wasting, cramps and stiffness of arms and/or legs, problems with speech and/or swallowing or, more rarely, with breathing problem [44]. The etiopathogenesis of MND is unknown and the aim of the cure is to maintain functional ability and enabling MND patients to live life as fully as possible [45].

Multiple sclerosis (MS) is a CNS chronic inflammatory disease that is caused by autoimmune-mediated loss of myelin and axonal damage. Its etiopathogenesis is poorly understood. MS is the most common neurological disorder affecting young adults, with a total of 2.5 million people in worldwide [46]. It causes a range of relapsing symptoms during the early phase of the disease, but becomes more persistent and less amenable to treatment at later stages. The research focused on identifying treatments that slow progression of neurodegeneration and also restore myelin of affected CNS regions [47].

\section{Citrus Flavonoids}

The genus Citrus belongs to the family Rutaceae, subfamily Aurantioideae, tribe Citreae, subtribe Citrinae. According to statistics of Food and Agriculture Organization of the United Nations (FAO), Citrus species are grown in more than 140 countries. China, Brazil, USA, India, Mexico, and Spain are the world's leading Citrus fruit-producing countries, representing close to two-thirds of global production (FAO STAT) [48].

The basic structural feature of flavonoid is 2-phenyl-benzo- $\gamma$-pyrane nucleus, contains a C6-C3-C6 heterocyclic skeleton, consisting of two benzene rings linked through a heterocyclic pyran ring. Based on the oxidization of the heterocyclic (C3) ring, Citrus flavonoids can be divided in flavanones, flavonols, flavones, and polymethoxiflavone (Figure 1). Anthocyanins are considered as metabolites of flavones and are present only in blood oranges. Structurally, they derived from pyran or flavan. Flavonoids are mainly present in plants as glycosides, while aglycones (the forms lacking sugar moieties) occur less frequently. Therefore, the large number of flavonoids is a result of many different 
combinations of aglycones and sugars, mainly D-glucose and L-rhamnose, bounded the hydroxyl group at the $\mathrm{C}-3$ or $\mathrm{C}-7$ position.
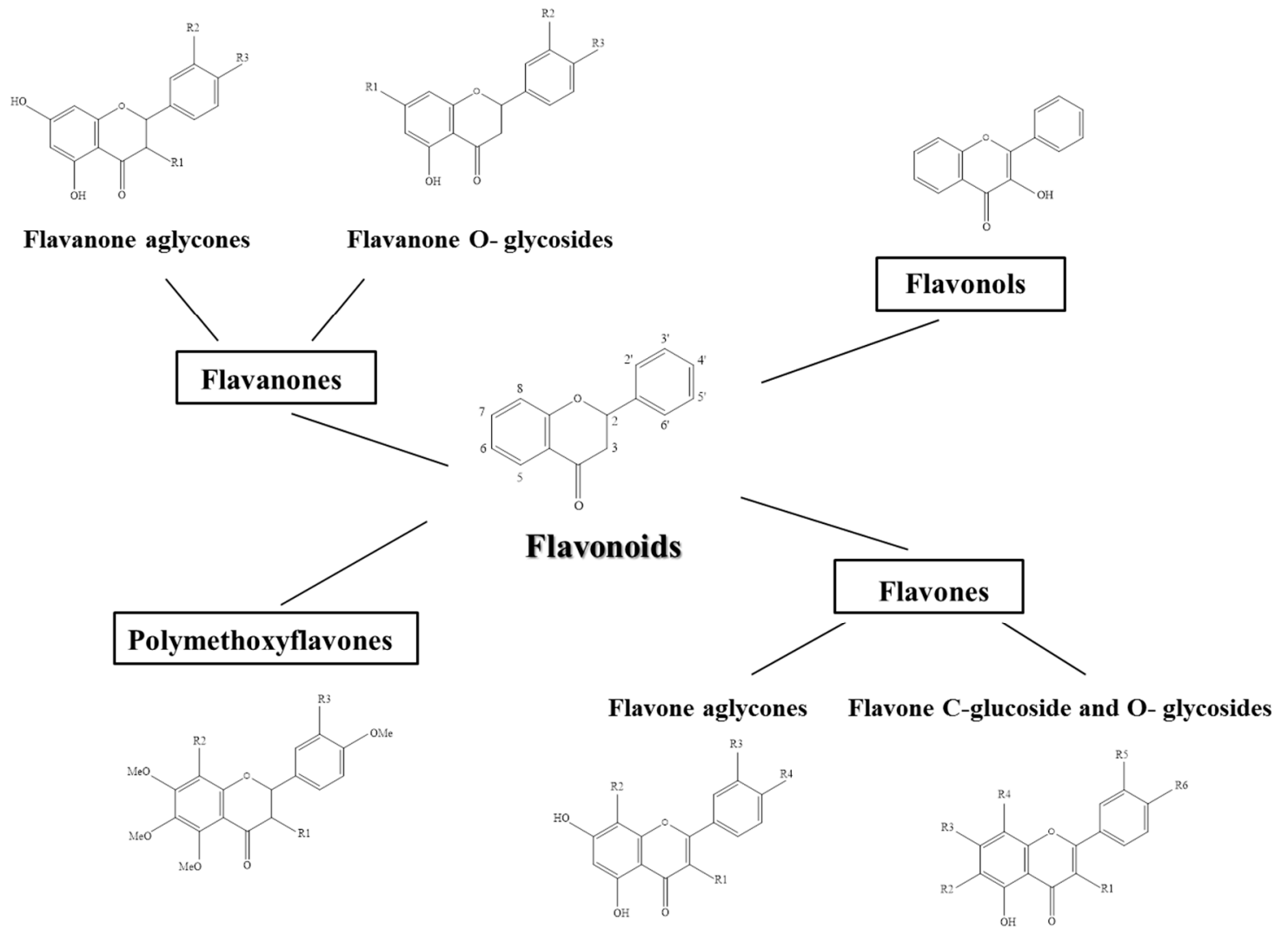

Figure 1. Chemical structure of Citrus flavonoids subclasses.

Flavanones comprise approximately $95 \%$ of the total flavonoids. Their concentration depends on the age of the plant, and the highest levels are detected in tissues, showing pronounced cell divisions [49]. They are present in both the glycoside and aglycone forms. Glycosylation occurs at position 7 either by rutinose or neohesperidose. The most important flavanones present in the aglycone forms are naringenin and hesperetin. Among flavanones with neohesperidose (rhamnosyl- $\alpha-1,2$ glucose), naringin, neoeriocitrin, neohesperedin and poncirin are the most abundant. Hesperidin, narirutin, eriocitrin and didymin are the main flavanone with rutinose (rhamnosyl- $\alpha-1,6$ glucose). Luteolin and diosmetin are the most present flavones in the aglycone form, while diosmin and neodismin represent the major flavones in the rutinosides and neohesperidosides forms, respectively [50]. Flavonols are the 3-hydroxy derivatives of flavones. Glycosylation occurs preferentially at the 3-hydroxyl group of the central ring. The most common flavonol aglycones are quercetin and kaempferol, while rutin and rutinosides are the main in the glycosidic form. Even if present in smaller quantities, the most common polymethoxiflavones are tangeretin and nobiletin. The chemical structures of Citrus flavonoids discussed in this review are presented in Figure 2. 


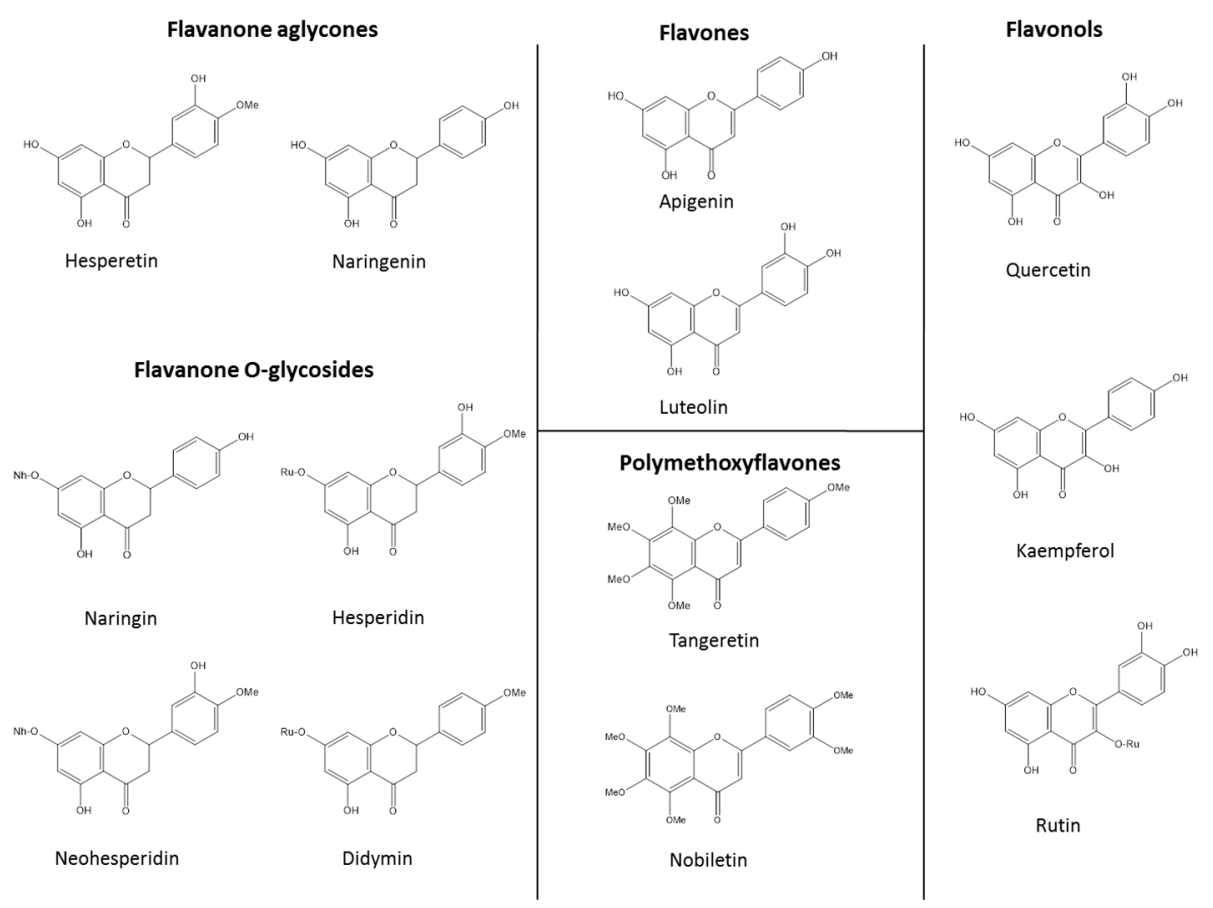

Figure 2. Molecular structure of Citrus flavonoids discussed in this review. Rutinose (Ru), neohesperidose $(\mathrm{Nh})$, methoxy $(\mathrm{Me})$.

\subsection{Flavanones}

In Table 1 are summarized the studies reporting the neuroprotective activity of Citrus flavanones.

Table 1. Citrus flavanones and experimental models of neurodegenerative diseases.

\begin{tabular}{|c|c|c|c|}
\hline Flavanones & Model & Disease/Condition & References \\
\hline \multirow{5}{*}{ naringin } & In vivo & $\mathrm{MPP}^{+}$-treated rats & Leem et al., 2014 [51] \\
\hline & In vivo & 6-OHDA-injected mice & Kim et al., 2016 [52] \\
\hline & In vivo & 3-NP-injected rats & Gopinath and Sudhandiran, 2012 [53] \\
\hline & In vivo & aluminum-treated rats & Prakash et al., 2013 [54] \\
\hline & In vivo & colchicine-treated rats & Kumar et al., 2010 [55] \\
\hline \multirow{8}{*}{ hesperidin } & In vivo & 6-OHDA-injected mice & Antunes et al., 2014 [56] \\
\hline & In vivo & 3-NP-treated mice & Menze et al., 2012 [57] \\
\hline & In vivo & APP/PS1-21 transgenic mice & Li et al., 2015 [58] \\
\hline & In vivo & APPswe/PS1dE9 transgenic mice & Wang et al., 2014 [59] \\
\hline & In vivo & ICV-STZ-injected mice & Javed et al., 2015 [60] \\
\hline & In vivo & $\mathrm{AlCl}_{3}$-injected rats & Thenmozhi et al., 2015 [61] \\
\hline & In vivo & $\mathrm{AlCl}_{3}$-injected rats & Thenmozhi et al., 2016 [62] \\
\hline & In vivo & $\begin{array}{l}\text { 4-AP-treated rats } \\
\text { KA-injected rat }\end{array}$ & Chang et al., 2015 [63] \\
\hline \multirow{4}{*}{ hesperetin } & In vivo & Mice & Choi and Ahn, 2008 [64] \\
\hline & In vivo & 6-OHDA-injected rats & Kiasalari et al., 2016 [65] \\
\hline & In vitro & staurosporine-treated cortical neurons cultures & Rainey-Smith et al., 2008 [66] \\
\hline & In vitro & $\mathrm{H}_{2} \mathrm{O}_{2}$-treated cortical neurons & Vauzour et al., 2007 [67] \\
\hline neohesperidin & In vitro & $\mathrm{H}_{2} \mathrm{O}_{2}$-treated PC12 cells & Hwang et al., 2008 [68] \\
\hline \multirow{5}{*}{ naringenin } & In vivo & ICV-STZ-injected rats & Khan et al., 2012 [69] \\
\hline & In vivo & ICV-STZ-injected rats & Baluchnejadmojarad and Roghani, 2006 [70] \\
\hline & In vitro & $\mathrm{A} \beta$-treated $\mathrm{PC} 12$ cells & Heo et al., 2004 [71] \\
\hline & In vitro & microglial cells & Wu et al., 2016 [72] \\
\hline & In vitro & LPS/IFN- $\gamma$ exposed primary neuronal-glial cells & Vafeiadou et al., 2009 [73] \\
\hline didymin & In vitro & $\mathrm{H}_{2} \mathrm{O}_{2}$-treated neuronal cells & Morelli et al, 2014 [74] \\
\hline
\end{tabular}

\subsubsection{Naringin}

Naringin is a major flavanone glycoside in Citrus fruits and it is considered a neuroprotective agent mainly because its anti-apoptotic [75,76] and anti-oxidant activities [77], together with its 
capability to induce neurotrophic factors such as brain-derived neurotrophic factor (BDNF) and vascular endothelial growth factor (VEGF). Recently, Leem and coworkers (2014) evaluated the effect of naringin in a neurotoxic model of PD in vivo. They found that the flavanone could prevent the degeneration of the nigrostriatal dopaminergic (DA) projection by increasing the level of glia-derived neurotrophic factor (GDNF) in nigral DA neurons, with activation of mammalian target of rapamycin complex 1 (mTORC1). Furthermore, they observed that naringin could attenuate the rise of TNF- $\alpha$ induced by 1-methyl-4-phenylpyridinium $\left(\mathrm{MPP}^{+}\right)$in microglia, indicating its anti-inflammatory activity in CNS [51]. Very recently, the same research group evaluated the effects of pre- or post-treatment with naringin in a 6-hydroxydopamine (OHDA)-treated mice [52], suggesting that it protected the nigrostriatal DA projection from 6-OHDA-induced neurotoxicity by both the activation of mTORC1 and the inhibition of microglial activation [51]. In 2012, Gopinath and Sudhandiran investigated on the neuroprotective effect of naringin on 3-nitropropionic acid (3-NP)-induced neurodegeneration [53]. The 3-NP is a natural environmental toxin that causes selective neuronal degeneration in the striatum, reproducing in animal models the brain lesions observed in HD patients [78]. The experimental protocol required that rats received naringin orally (80 mg/kg body weight/day) $1 \mathrm{~h}$ prior to the intraperitoneal injection of 3-NP $(10 \mathrm{mg} / \mathrm{kg}$ body weight/day) for 2 weeks (the time to develop neurodegeneration). The Authors observed that naringin can mitigate 3-NP-induced neurodegeneration, through the enhancement of antioxidant enzyme gene expressions via nuclear factor E2-related factor 2 (Nrf2) activation, thus modulating oxidative stress and inflammatory responses.

In the last decade, flavonoids have been used to reduce neurotoxic effects of aluminum ( $\mathrm{Al}$ ) chloride $\left(\mathrm{AlCl}_{3}\right)$ in rats. In this field, Prakash and collaborators (2013), explored the possible role of naringin against Al-induced cognitive dysfunction and oxidative damage in rats. The Authors observed that chronic administration of naringin (40 and $80 \mathrm{mg} / \mathrm{kg}$ ) for six weeks significantly improved cognitive performance and attenuated mitochondria oxidative damage, acetyl cholinesterase activity, and Al concentration in Al-treated $(100 \mathrm{mg} / \mathrm{kg})$ rats [54]. The same authors showed that treatment with naringin (40 and $80 \mathrm{mg} / \mathrm{kg} /$ day) for 25 consecutive days beginning 4 days prior to colchicine $(15 \mu \mathrm{g} / 5 \mu \mathrm{L})$ injected intracerebroventricularly significantly improved the cognitive performance and attenuated oxidative damage in colchicine-treated rats [55].

\subsubsection{Hesperidin}

Hesperidin, a flavonoid that is particularly abundant in oranges and lemons, exerts anticarcinogenic, antihypertensive, antiviral, antioxidant and antiinflammatory effects [79]. In addition, hesperidin can cross the blood-brain barrier [80] and can protect the neurons against various types of insult associated with neurodegenerative diseases, including AD, PD, and HD. A study performed by Antunes and collaborators (2014) was aimed to evaluate the role of hesperidin in an animal model of PD induced by 6-OHDA. The Authors demonstrated that hesperidin (50 mg/ kg), administrated for 28 days after an intracerebroventricular injection of 6-OHDA, was effective in preventing memory impairment and depressive-like behavior in mice. Furthermore, in the striatum of aged mice, hesperidin attenuated the 6-OHDA-induced reduction in (i) glutathione peroxidase (GPx) and catalase (CAT) activity, (ii) the total reactive antioxidant potential and (iii) the dopamine levels. Finally, the flavanone mitigated both the increased levels of ROS and the activity of glutathione reductase induced by 6-OHDA [56].

The implications of nitric oxide (NO) in a variety of neurodegenerative diseases suggests a potential role of flavonoids in HD and other oxidative-based disorders. Menze et al., (2012) investigated the potential effect of hesperidin on 3-NP-induced behavioral, neurochemical, histopathological and cellular changes. They showed that pretreatment with hesperidin $(100 \mathrm{mg} / \mathrm{kg})$ ahead of 3-NP $(20 \mathrm{mg} / \mathrm{kg}$ ) for 5 days prevented any changes of locomotor activity or prepulse inhibition, slightly increased malondialdehyde (MDA) levels and reduced inducible nitric oxide synthase (iNOS) positive cells as well as CAT activity in cortex, striatum and hippocampus evoked by 3-NP [57]. 
One of the most distinctive neuropathological characteristics of AD, are the senile plaques of aggregates $\mathrm{A} \beta$ peptide. Moreover, besides the well-known A $\beta$ aggregation, neuro-inflammation also plays a pivotal role in the etiopathogenesis of this multifactorial disorder [81]. Li and coworkers (2015), evaluated the potential therapeutic effect of hesperidin on behavioral dysfunction, $\mathrm{A} \beta$ deposition and neuro-inflammation in the transgenic APP/PS1 mouse, a useful model of cerebral amyloidosis for AD. Hesperidin (100 mg/kg body weight) was orally given to the mice for 10 days. It recovered deficits in non-cognitive nesting capability and social interaction and attenuated A $\beta$ deposition, plaque associated amyloid precursor protein (APP) expression, microglial activation and TGF- $\beta 1$ immunoreactivity in both cerebral cortex and hippocampus of APP/PS1 mice [58]. The same dose of hesperidin (100 mg/kg) administrated for 16 weeks to three-month-old APPswe/PS1dE9 transgenic mice reduced their learning and memory deficits, improved locomotor activity and increased glycogen synthase kinase-3 $\beta$ (GSK-3 $\beta$ ) phosphorylation, anti-oxidative defense and mitochondrial complex I-IV enzymes activities [58]. However, there was not observed obvious change in A $\beta$ deposition [59]. Hesperedin was effective also in the experimental model of intracerebroventricular streptozotocin (ICV-STZ)-induced sporadic dementia of Alzheimer's type (SDAT) [60]. Indeed, pretreatment with hesperidin (100 or $200 \mathrm{mg} / \mathrm{kg} /$ day orally for 15 days) improved memory consolidation process possibly through modulation of acetylcholine esterase activity (AChE) in mice injected bilaterally with single dose of ICV-STZ $(2.57 \mathrm{mg} / \mathrm{kg}$ body weight each side). Moreover, hesperidin decreased neuronal cell death by reducing the overexpression of pro-inflammatory mediators like NF- $\kappa \mathrm{B}, \mathrm{iNOS}$, cyclooxygenase-2 (COX-2) and attenuated astrogliosis [60].

One of the key factors in the progression of neurodegenerative diseases is the deregulation of metal ion homeostasis, such as Al, a major risk factor for the AD [82]. Thenmozhi and coworkers (2015) evaluated the protective effect of hesperidin on $\mathrm{AlCl}_{3}$ induced neurobehavioral and pathological changes in Alzheimeric rats. Orally administration of hesperidin $(100 \mathrm{mg} / \mathrm{kg})$ along with $\mathrm{AlCl}_{3}$ injection $(100 \mathrm{mg} / \mathrm{kg}$ ) for 60 days, significantly reduced the $\mathrm{Al}$ concentration in hippocampus and cortex, the acetylcholinesterase (AChE) activity, the APP expressions, the levels of both $\mathrm{A} \beta_{1-42}$ and its synthesis-related molecules ( $\beta$ and $\gamma$ secretases). Moreover, hesperidin significantly attenuated the behavioral impairments caused by $\mathrm{AlCl}_{3}$ and preserved the normal histoarchitecture pattern of the hippocampus and cortex, as observed by histopathological studies [61]. Very recently, with the same experimental model Thenmozhi et al., (2016) showed that hesperidin prevented oxidative stress and apoptosis induced by $\mathrm{AlCl}_{3}$ compared to control group [62].

Excitotoxicity is considered one of the constitutive components of the neurodegenerative diseases pathogenesis [83] caused by excessive release of aminoacids such as glutamate, a crucial excitatory neurotransmitter in the mammals CNS. This provokes the overstimulation of glutamate receptors which leads to an overload of intracellular $\mathrm{Ca}^{2+}$, generation of free radicals and subsequent neuronal cell death [84]. Chang and coworkers (2015) evaluated the potential role of hesperidin in neurotoxicity induced by glutamate release in rat hippocampus. They observed that hesperidin ( $\mathrm{IC}_{50} 20 \mu \mathrm{M}$ ) inhibited both the release of glutamate and the elevation of cytosolic free $\mathrm{Ca}^{2+}$ concentration evoked by 4-aminopyridine (4-AP) in rat hippocampal nerve terminals (synaptosomes). Furthermore, in hippocampal slice preparations, whole-cell patch clamp experiments showed that hesperidin reduced the frequency of spontaneous excitatory postsynaptic currents without affecting their amplitude, indicating the involvement of a presynaptic mechanism. In addition, the Authors observed that pre-treatment with hesperidin $(10$ or $50 \mathrm{mg} / \mathrm{kg})$ attenuated the rise of extracellular glutamate and the neuronal loss in the hippocampal CA3 area caused by the intraperitoneal injection of kainic acid (KA; $15 \mathrm{mg} / \mathrm{kg}$ ) [63].

\subsubsection{Hesperetin}

Hesperetin is a flavanone abundant in Citrus fruit and juice, and represents the major circulating aglycone metabolite of hesperidin. Hesperetin displays several biological properties, such as antioxidant, neuroprotective and anti-inflammatory activities. 
Experiments performed in vitro showed that $1 \mu \mathrm{M}$ hesperetin has neuroprotective effects against $\mathrm{H}_{2} \mathrm{O}_{2}$-induced cytotoxicity in PC12 cells [68], and that much lower concentrations both inhibit $\mathrm{H}_{2} \mathrm{O}_{2}$-induced apoptosis and counteract staurosporine-induced cell death in primary cortical neurons $(0.01 \mu \mathrm{M} / \mathrm{L}$ and $300 \mathrm{nM}$, respectively) [66,67], suggesting its potential role in the intervention for neurodegenerative diseases.

In vivo, Choi and Ahn (2008) observed that hesperetin (10 or $50 \mathrm{mg} / \mathrm{kg}$ body weight) inhibited biomarkers of oxidative stress, such as the thiobarbituric acid-reactive substance (TBARS) and carbonyl, in the brains of mice, and activated both CAT and superoxide dismutase (SOD). Moreover, hesperetin increased the reduced glutathione (GSH) / oxidized glutathione (GSSG) ratio, the glutathione peroxidase (GSH-px) and the glutathione reductase (GR) activities [64]. Very recently, Kiasalari and coworkers (2016), evaluated the protective effect of hesperetin against 6-OHDA-induced striatal lesion and have explored some underlying mechanisms including apoptosis, inflammation and oxidative stress. They administrated hesperetin $(50 \mathrm{mg} / \mathrm{kg} /$ day) for 1 week at intrastriatal 6-OHDA-lesioned rats. They observed that hesperetin reduced the rotational asymmetry induced by apomorphine, as well as the latency and the total time on the narrow beam task. It also decreased striatal malondialdehyde and increases both striatal CAT activity and GSH content. Moreover, hesperetin lowered striatal level of glial fibrillary acidic protein (GFAP) and increased $\mathrm{Bcl}_{2}$ [65]. Finally, hesperetin treatment was also capable to mitigate nigral DNA fragmentation and to prevent loss of SNC dopaminergic neurons [65].

\subsubsection{Neohesperidin}

Neohesperidin is a flavanone glycoside found in Citrus fruits. Hwang and coworkers (2008) demonstrated the protective effects of pretreatments $(6 \mathrm{~h})$ with neohesperidin, hesperidin and hesperetin $(0.8,4,20$, and $50 \mu \mathrm{M})$ on $\mathrm{H}_{2} \mathrm{O}_{2}$-induced $(400 \mu \mathrm{M}, 16 \mathrm{~h})$ neurotoxicity in PC12 cells by scavenging ROS, attenuating the elevation of intracellular free $\mathrm{Ca}^{2+}$, preventing membrane damage and increasing CAT activity. Furthermore, neohesperidin attenuated both the decrease of mitochondrial membrane potential and the increase of caspase-3 activity evoked by $\mathrm{H}_{2} \mathrm{O}_{2}$ [68].

\subsubsection{Naringenin}

It is known that naringenin possesses various pharmacologic properties including antioxidant, free radical scavenger, anticancer, anti-inflammatory, immunomodulator and memory enhancer.

It's known that ICV-STZ administration at a sub-diabetogenic dose provided a relevant model for AD-type neurodegeneration with cognitive impairment (AD-TNDCI) [85,86]. In this field, Khan and collaborators (2012), investigated the effects of naringenin on cognitive dysfunction and, oxidative stress in a rat model of AD-TNDCI. The rats were orally pre-treated with naringin at $50 \mathrm{mg} / \mathrm{kg}$ for 2 weeks followed by ICV-STZ ( $3 \mathrm{mg} / \mathrm{kg} ; 5 \mu \mathrm{L}$ per site) injection bilaterally. The Authors observed that the imbalance of several markers of oxidative stress (enzymatic and non-enzymatic) with impairments in spatial learning and memory, loss of ChAT positive neuron and damage to hippocampal ones induced by ICV-STZ, were ameliorated by pre-treatment with naringenin [69]. The ability of naringenin to improve learning, memory and cognitive impairment was also confirmed by Baluchnejadmojarad and Roghani (2006) in an experimental model very similar to those described above [70].

Heo et al., (2004) examined the neuroprotective effect of naringenin found in C. junos against oxidative cell death induced by A $\beta$ peptide in PC12 cells, and evaluated the anti-amnesic activity of naringenin using ICR mice with scopolamine-induced amnesia ( $1 \mathrm{mg} / \mathrm{kg}$ body weight). They showed that pretreatment with naringenin prevented the generation of $A \beta$-induced ROS and decreased $A \beta$ toxicity in a concentration dependent manner. Furthermore, naringenin $(4.5 \mathrm{mg} / \mathrm{kg}$ body weight), significantly ameliorated scopolamine-induced amnesia [71]. Vafeiadou and coworkers (2009) [73] demonstrated that naringenin $(0.01-0.3 \mu \mathrm{mol} / \mathrm{L})$ protected against LPS/IFN-gamma-induced neuronal death in a primary neuronal-glial co-culture system by inhibiting the p38 mitogen-activated protein kinase (MAPK) phosphorylation and downstream signal transducer and activator of transcription-1 (STAT-1). 
More recently, $\mathrm{Wu}$ and coworkers (2016) demonstrated that naringenin inhibits the expression of cytokine signaling (SOCS)-3, iNOS and COX-2, as well as the release of NO and pro-inflammatory cytokines in microglial cells. These actions were modulated by adenosine monophosphate-activated protein kinase $\alpha(\mathrm{AMPK} \alpha)$ and protein kinase $\mathrm{C} \delta(\mathrm{PKC} \delta)$ [72].

\subsubsection{Didymin}

Only one paper suggested a neuroprotective effect of didymin that was found to increase cell viability of neuronal cells injured by $\mathrm{H}_{2} \mathrm{O}_{2}$ by decreasing mitochondrial dysfunctions and levels of intracellular ROS, stimulating SOD, CAT and GPx activity [74]. The mechanism underlying the protective effects of didymin in differentiated-SH-SY5Y exposed to $\mathrm{H}_{2} \mathrm{O}_{2}$ might be related to the activation of antioxidant defense enzymes as well as to the inhibition of apoptotic features such as p-JNK and caspase-3 [74].

\subsection{Flavones}

\subsubsection{Apigenin}

Apigenin is a member of the flavone subclass of flavonoids present in fruits and vegetables. It has long been considered to have various biological activities such as antioxidant, antiinflammatory, anti-mutagenic and anti-tumorigenic properties. Apigenin has been shown to exert neuroprotective activity against endoplasmic reticulum stress-induced apoptosis in the HT22 murine hippocampal neuronal cells [87], in primary cultures of human neurons subjected to quinoloinic acid-induced excitotoxicity [88] and in glutamate-induced neurotoxicity in both murine cerebellar and cortical cell cultures [89].

Zhao et al. (2013) [90] reported the neuroprotective effects of the flavone in the amyloid precursor protein/presenilin 1 protein (APP/PS1) double transgenic AD mouse model. After feeding four month-old mice with apigenin $(40 \mathrm{mg} / \mathrm{kg}$ ) for 3 months, they observed both improvements in memory and learning deficits and reduction of fibrillar amyloid deposits. Additionally, the apigenin-treated mice showed restoration of the cortical extracellular signal-regulated protein kinase 1 (ERK)/ cAMP response element-binding protein (CREB)/BDNF pathway that is known to be involved in learning and memory typically affected AD patients. Finally, apigenin enhances both SOD and GPx activities [90]. Likewise, in $A \beta_{25-35}$-induced amnesia mouse models, Liu et al. (2011) reported the capability of apigenin $(20 \mathrm{mg} / \mathrm{kg})$ to improve the spatial learning and memory and the neurovascular functionality [91]. Cognitive enhancing effects by apigenin $(20 \mathrm{mg} / \mathrm{kg}$, intraperitoneally) have been described also in an animal model in which the flavone delayed the long-term forgetting [92]. Another study performed by Taupin et al. (2009) highlighted that the administration of apigenin $(25 \mathrm{mg} / \mathrm{kg}$ ) for 10 days stimulated neurogenesis in the hippocampal region of the brain in 7-week old mice and resulted in improved performance in the Morris water maze [93]. Patil and its research group demonstrated that chronic intraperitoneally administration of apigenin $(5-20 \mathrm{mg} / \mathrm{kg})$ reversed cognitive deficits in aged and lipopolysaccharide (LPS)-intoxicated mice [94]. Additionally, apigenin improved motor skills and enhanced neurotrophic potential which has been reduced in 1-methyl-4-phenyl-1,2,3,6-tetrahydropyridine (MPTP)-induced Parkinsonism in mice [95]. Particularly, MPTP $(25 \mathrm{mg} / \mathrm{kg})$ was administrated for five consecutive days and then apigenin (10 and $20 \mathrm{mg} / \mathrm{kg})$ was orally administrated for 26 days, including 5 days of pretreatment. After that, the Author performed behavioral study and biochemical estimation of oxidative stress biomarkers, observing (i) a reduced tyrosine hydroxylase (TH)-positive cells; (ii) a rise of BDNF amount and (iii) a decreased level of GFAP in the substantia nigra of MPTP-treated mice [95]. More recently, Liu et al. (2015) demonstrated that apigenin exerts a protective effect against $\mathrm{MPP}^{+}$-induced neurotoxicity in neuronal like catecholaminergic PC12 cells. This effect is mediated through the inhibition of oxidative stress, the stabilization of mitochondrial function and the reduction of neuronal apoptosis via the mitochondrial pathway [96]. The cytoprotective effect of apigenin was also evaluated by Wu and 
coworkers (2015), showing that apigenin restored cell viability and repressed both caspase-3 and PARP-1 activation in 4-HNE-treated PC12 cells. Moreover, apigenin activated MAPK and Nrf2 signaling, which in turn evoked adaptive cellular stress response pathways, restored ER homeostasis altered by 4-HNE and inhibited cytotoxicity [97].

Table 2 reported the studies in which was evaluated apigenin as potential neuroprotective agent.

Table 2. Studies employed the Citrus flavones and their experimental models of neurodegeneration.

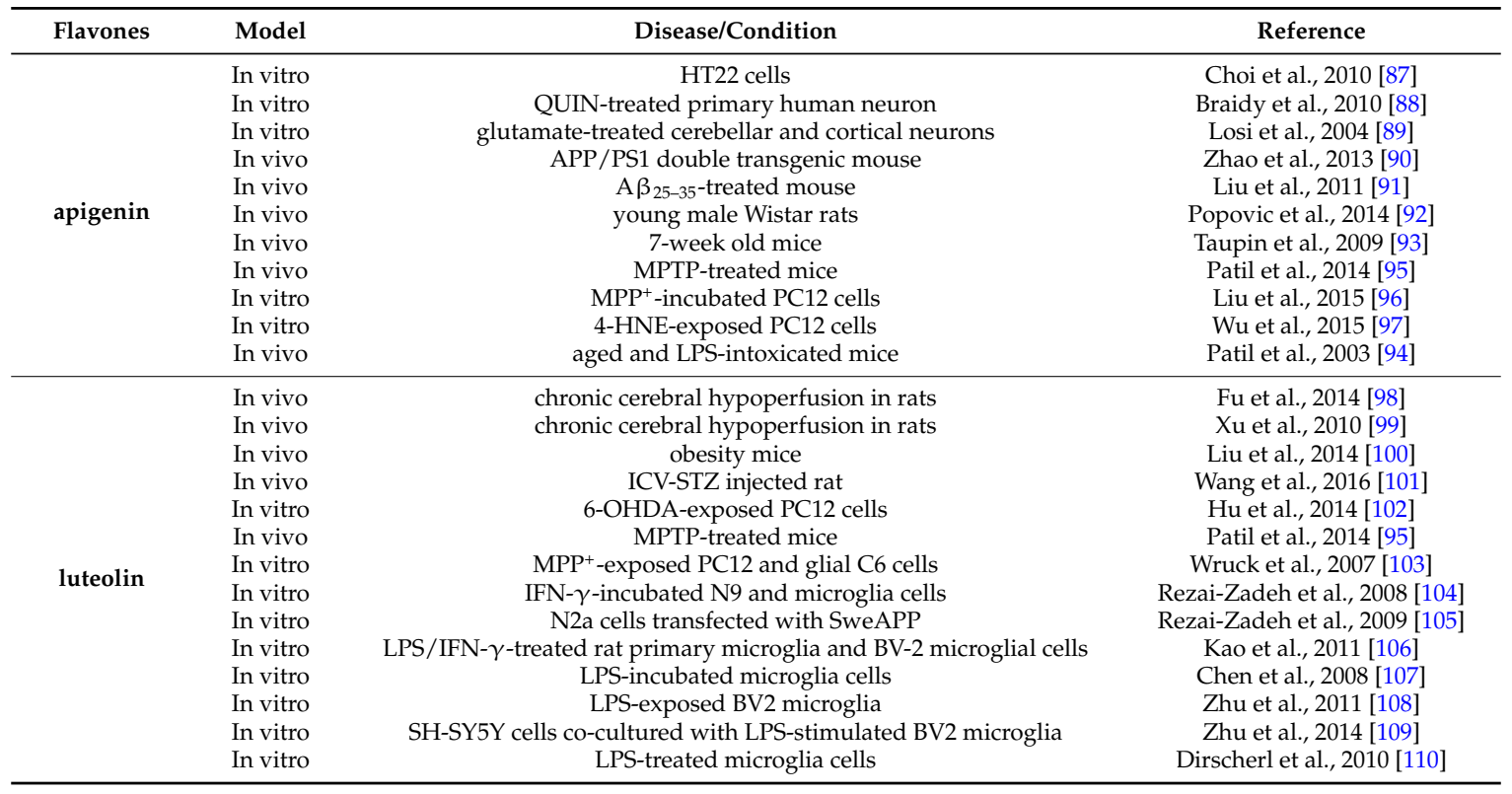

\subsubsection{Luteolin}

In the last decades, several studies reported the neuroprotective properties of luteolin [111]. They are summarized in Table 2. In vivo studies showed that luteolin protected against cognitive dysfunction induced by chronic cerebral hypoperfusion in rats $[98,99]$. Luteolin also protected against high fat diet-induced cognitive defects in obesity mice [100]. Recently, Wang et al., (2016) demonstrated that the flavone significantly ameliorated the spatial learning and memory impairment and increased the thickness of CA1 pyramidal layer in STZ-treated animals [101]. Moreover, luteolin $(20 \mu \mathrm{M})$ can attenuate 6-OHDA-caused oxidative stress, cytotoxicity, and caspase-3 activation in PC12 cells [102]. Another study displayed as luteolin (10 and $20 \mathrm{mg} / \mathrm{kg}$ ) could improve locomotor and muscular alterations in mice exposed to MPTP, also decreasing the TH-positive cells, the neurotrophic factors, the GFAP, and the BDNF [95]. In addition, Wruck et al., (2007) demonstrated that luteolin protected rat neural PC12 and glial C6 cells from $\mathrm{MPP}^{+}$-induced toxicity and activated Nrf2 [103]. The research group of Rezai-Zadeh (2008) demonstrated that treatment of both N9 and murine-derived primary microglia cell lines with luteolin significantly reduced both the IFN- $\gamma$-induced CD40 expression and the release of pro-inflammatory cytokines IL-6 and TNF- $\alpha$ through the inactivation of STAT1 [104]. One year later, the same authors showed that luteolin treatment of murine N2a cells transfected with SweAPP and primary neuronal cells derived from SweAPP overexpressing mice resulted in a significant reduction in $A \beta$ generation. The mechanism seems to be involved in the selective inactivation of the GSK-3 $\alpha$ isoform, which in turn increases the phosphorylation of PS1, the catalytic core of the $\gamma$ secretase complex, thereby reducing PS1 APP interaction and A $\beta$ generation [105].

Excessive production of NO and pro-inflammatory cytokines by activated microglia plays a pivotal role in the pathogenesis of ND. Kao and collaborators (2011) reported the inhibitory effect of luteolin on LPS/interferon $\gamma$ (IFN- $\gamma$ )-induced NO and cytokines production in rat primary microglia and BV-2 microglial cells. Particularly, luteolin concentration-dependently abolished LPS/IFN- $\gamma$-induced NO, TNF- $\alpha$ and IL-1 $\beta$ production as well as iNOS expression. Luteolin also 
exerted inhibitory effect on transcription factor activity including NF- $\mathrm{B}$, signal transducer and activator of transcription 1 (STAT1) and interferon regulatory factor 1 (IRF-1). These effects were accompanied by down-regulation of ERK, p38, JNK, protein kinase B (Akt) and Src [106].

Chen and coworkers (2008) demonstrated that luteolin may protect dopaminergic neurons from LPS-induced injury and its efficacy in inhibiting microglia activation [107]. Another research showed that luteolin inhibited the LPS-stimulated expression of inducible iNOS, COX-2, TNF- $\alpha$ and IL- $1 \beta$ as well as blocked the LPS-induced NF- $\mathrm{B}$ B activation [108]. A few years later, the same authors, demonstrated that luteolin inhibited the LPS-stimulated expression of TLR-4, blocked LPS-induced NF- $\mathrm{B}, \mathrm{p} 38$, JNK and Akt activation, but had no effect on ERK. In addition, pre-treatment with luteolin increased cell viability and reduced apoptosis of SH-SY5Y cells co-cultured with LPS-stimulated BV2 microglia [109]. To better understand the immuno-modulatory effects of luteolin, Dirscherl et al., (2010) carried out a genome-wide expression study in LPS-exposed BV-2 microglia cells treated with luteolin and performed a phenotypic and functional profile. They observed that luteolin suppressed pro-inflammatory marker expression in LPS-activated microglia and triggered global changes in the microglial transcriptome with more than 50 differentially expressed transcripts. Moreover, pro-inflammatory and pro-apoptotic gene expression was blocked by luteolin, while mRNA levels of genes involved into anti-oxidant metabolism, phagocytosis, ramification, and chemotaxis were significantly induced [110].

\subsection{Flavonols}

\subsubsection{Kaempferol}

There are few evidences for the neuroprotective effect of kaempferol (Table 3). LPS-activated microglial cells have been suggested to be a useful in vitro model to test the potential of drugs for neuroinflammatory disorders [112,113]. Park and coworkers (2011) demonstrated the activity of kaempferol against neuroinflammatory toxicity caused by LPS-activated microglia. Particularly, they showed that kaempferol inhibit the LPS-induced expression of iNOS, COX-2, matrix metalloproteinases (MMPs) and the subsequent production of ROS, TNF- $\alpha, N O$, PGE2 and IL-1 $\beta$ in BV2 microglial cells, through the inhibition of TLR4, NF- $\mathrm{B}$, p38 MAPK, JNK and AKT activation [114]. Yang and collaborators (2014) demonstrated the neuroprotective effects of kaempferol in glutamate-treated hippocampal neuronal cells, suggesting that kaempferol may be a useful candidate for neurodegenerative diseases [115].

Table 3. Citrus flavonols kaempferol and rutin in models of neurodegenerations.

\begin{tabular}{|c|c|c|c|}
\hline Flavonols & Model & Disease/Condition & Reference \\
\hline \multirow{2}{*}{ kaempferol } & In vitro & LPS-activated microglia & Park et al., 2011 [114] \\
\hline & In vitro & glutamate-treated hippocampal neuronal & Yang et al., 2014 [115] \\
\hline \multirow{10}{*}{ rutin } & In vitro & 6-OHDA-incubated PC-12 cells & Magalingam et al., 2013 [116] \\
\hline & In vitro & ethanol-exposed HT22 cells & Song et al., 2014 [117] \\
\hline & In vitro & amylin-treated SH-SY5Y cells & Yu et al., 2015 [118] \\
\hline & In vitro & neuronal cells & $\mathrm{Na}$ et al., 2014 [119] \\
\hline & In vivo & KA-injected BALB/c mice & Nasiri-Asl et al., 2013 [120] \\
\hline & In vivo & 6-OHDA-treated rats & Kham et al., 2012 [121] \\
\hline & In vitro & $\mathrm{Ab}_{42}$-incubated SH-SY5Y cells & Wang et al., 2012 [122] \\
\hline & In vivo & APPswe/PS1dE9 transgenic mice & Xu et al., 2014 [123] \\
\hline & In vivo & mice & Machawal and Kumar, 2014 [124] \\
\hline & In vivo & $\mathrm{A} \beta$-injected rats & Moghbelinejad et al., 2014 [125] \\
\hline
\end{tabular}

\subsubsection{Rutin}

Rutin is a multifunctional flavonoid glycoside acting on various cellular functions under pathological conditions such as ND, maybe due to its ability to cross the blood brain barrier (BBB) [126]. Table 3 summarizes the studies aimed to evaluate the effects of rutin in models of neurodegenerations. 
In an in vitro model of $\mathrm{PD}$, it has been demonstrated that rutin reduced lipid peroxidation in 6-OHDA-treated PC-12 cells, activating antioxidant enzymes like SOD, CAT, GPx and GSH [116]. The neuroprotective effects of rutin against 6-OHDA were evaluated also in vivo. Rats was pre-treated with this flavonoids ( $25 \mathrm{mg} / \mathrm{kg}$ body weight, orally) for 3 weeks and then subjected to unilateral intrastriatal injection of 6 -OHDA ( $10 \mu \mathrm{g}$ in $0.1 \%$ ascorbic acid). Rutin prevented the deficits in locomotor activity and motor coordination, and protected neurons from deleterious effects of 6-OHDA in the substantia nigra, as suggested by histopathological and immunohistochemical assays [121].

Oxidative stress has been proposed to be a potential mechanism underlying ethanol-induced damage and may contribute to neuronal degeneration [127]. Song et al., (2014) investigated the antioxidant effect of rutin in hippocampal neuronal cells exposed to ethanol, and found that it prevented the ethanol-induced decrease in nerve growth factor expression, GDNF and BDNF in HT22 cells. Moreover, rutin significantly increased the level of the antioxidant glutathione, and the activities of SOD and CAT [117]. Oxidative stress may play a role also in hippocampal cell death associated with KA-induced neurotoxicity [128]. It has been reported that rutin (100 and $200 \mathrm{mg} / \mathrm{kg}$, i.p. for 7 days) has potential anticonvulsant and antioxidative activities against oxidative stress in KA-induced (10 mg/kg, i.p.) seizures in mice [120].

Wang and coworkers (2012) showed that rutin can inhibit $\mathrm{A} \beta_{42}$ fibrillization in concentration dependent manner and can attenuate $\mathrm{A} \beta_{42}$-induced cytotoxicity in SH-SY5Y neuroblastoma cells [122]. More recently, the same authors demonstrated that orally administered rutin significantly attenuated memory deficits in APPswe/PS1dE9 transgenic mice, decreased oligomeric A $\beta$ level, reduced oxidative stress, downregulated gliosis and diminished IL-1 and IL-6 levels in the brain [123]. Another study suggested a role for rutin in protecting against AD. Moghbelinejad and coworkers (2014) showed that rutin improved memory retrieval in rats injected with A $\beta$ by increasing ERK1, CREB and BDNF [125].

Recently, Yu et al., (2015) showed that rutin inhibited amylin-induced neurocytotoxicity, decreasing the production of ROS, NO, glutathione disulfide (GSSG), MDA, TNF- $\alpha$ and IL- $1 \beta$, thus attenuating mitochondrial damage and increasing the GSH/GSSG ratio. These protective effects could be derived by its ability to inhibit amylin aggregation, enhance the activity of SOD, CAT, and GPx, and reduce that of iNOS [118]. Machawal and Kumar (2014) suggested that the neuroprotective mechanism of rutin against immobilization stress-induced anxiety-like behavioral and oxidative damage in mice is mediated by a reduction of NO [124]. Finally, it has been proposed that rutin protects against the neurodegenerative effects of prion accumulation in vitro, by reducing levels of ROS and NO, increasing production of neurotropic factors and inhibiting mitochondrial apoptotic events leading to HT22 neuronal cell death [119].

\subsubsection{Quercetin}

Quercetin exhibits numerous pharmacological activities including anti-cancer, anti-inflammatory, anti-atherosclerotic, anti-thrombotic and anti-hypertensive effects, as well as benefits for human endurance exercise capacity. Several in vitro and in vivo studies have provided supportive evidence also for its neuroprotective effects in various models of neuronal injury and chronic neurodegenerative diseases (Table 4). In vitro studies have shown that low micromolar concentrations of quercetin inhibited cell toxicity induced by neurotoxic molecules known to be inducer of oxidative stress. In particular, several research employed $\mathrm{H}_{2} \mathrm{O}_{2}$ as stressor. Suematsu et al., (2011) demonstrated that quercetin suppressed the $\mathrm{H}_{2} \mathrm{O}_{2}$-caused cytotoxicity and inhibited apoptosis in human neuronal SH-SY5Y cells [129]. Quercetin also decreased $\mathrm{H}_{2} \mathrm{O}_{2}$-induced oxidative stress in SK-N-MC cells by reducing HIF-1a, Foxo-3a, NICD and pro-apoptotic mediators including p53 and Bax [130]. The anti-oxidative and anti-apoptotic role of quercetin was further supported by the study of Jazvinšćak Jembrek and coworkers (2012) [131]. Sajad et al., (2013) showed that pre-treatment with quercetin prevented protein nitration and glycolytic block of proliferation in cultured neuronal precursor cells (NPCs) [132]. 
Table 4. Studies employed quercetin in experimental models of neurodegeneration.

\begin{tabular}{cccc}
\hline Flavonol & Model & Disease/Condition & Reference \\
\hline & In vitro & $\mathrm{H}_{2} \mathrm{O}_{2}$-incubated SH-SY5Y cells & Suematsu et al., 2011 [129] \\
In vitro & $\mathrm{H}_{2} \mathrm{O}_{2}$-exposed SK-N-MC cells & Roshanzamir and Yazdanparast, 2014 [130] \\
In vitro & $\mathrm{H}_{2} \mathrm{O}_{2}$-treated NPCs cells & Sajad et al., 2013 [132] \\
In vitro & $\mathrm{H}_{2} \mathrm{O}_{2}$-treated -P19 neurons & Jazvinšćak J et al., 2012 [131] \\
In vitro & neuronal cells & Ansari et al., 2009 [133] \\
In vivo & A $\beta$-injected mice & Zhang et al., 2016 [134] \\
In vivo & MPTP-treated mice & Lv et al., 2012 [135] \\
In vitro & LPS- and IFN- $\gamma$-treated BV-2 microglia & Chen et al., 2005 [136] \\
In vitro & LPS-treated BV-2 microglia & Kang et al., 2013 [137] \\
In vitro & high-glucose exposed PC12 cells & Bournival et al., 2012 [138] \\
In vivo & high-fat diet in mice & Xia et al., 2015 [139] \\
In vivo & high-cholesterol diet in mice & Lu et al., 2010 [140] \\
In vivo & intracerebral hemorrhage in rats & Zhang et al., 2015 [141] \\
In vivo & ischemia reperfusion injury in rats & Arikan et al., 2015 [142] \\
In vivo & STZ-treated mice & Tota et al., 2010 [143] \\
In vivo & scopolamine-treated zebrafish & Richetti et al., 2011 [144] \\
In vivo & Pb-exposed rats & Hu et al., 2008 [145] \\
In vivo & ethylmercury-exposed rats & Barcelos et al., 2011 [146] \\
In vivo & tungsten-exposed rats & Sachdeva et al., 2015 [147] \\
In vivo & Al-treated rats & Sharma et al., 2013 [148] \\
In vivo & Al -treated rats & Sharma et al., 2015 [149] \\
In vivo & Al -treated rats & Sharma et al., 2016 [150] \\
In vivo & PCBs-treated rats & Bavithra et al., 2012 [151] \\
In vivo & PCBs-treated rats & Selvakumar et al., 2013 [152] \\
In vivo & ethidium bromide-treated rats & Beckmann et al., 2014 [153] \\
\hline
\end{tabular}

Protection of neuronal cells from the toxicity of $A \beta$ peptide-induced toxicity has also been reported. Ansari et al., (2009) showed that low concentration of quercetin significantly attenuated protein oxidation, lipid peroxidation and apoptosis induced by $\mathrm{A} \beta_{1-42}$ in neuronal cultures [133], while Zhang et al., (2016) demonstrated that quercetin enhanced brain apoE levels and decreased A $\beta$ levels in the cortex of amyloid model mice [134]. Moreover, the orally administration of quercetin (50, 100 and $200 \mathrm{mg} / \mathrm{kg}$ body weight) markedly improves MPTP-induced dopamine depletion in the brain tissue, the motor balance and the coordination which is significantly altered following MPTP injection in an animal model of PD [135].

In 2005, Chen and collaborators, demonstrated that quercetin suppressed LPS- and IFN- $\gamma$-induced NO production and iNOS gene transcription and enhanced heme oxygenase-1 (HO-1) expression [136]. More recently, Kang and coworkers (2013) found that the suppression of NO system in BV2 microglial cell line is mediated by the inhibition of NF- $\mathrm{kB}$ and the induction of Nrf2/HO-1 [137]. Furthermore, quercetin protected neuronal PC12 cells from high-glucose-induced oxidation, nitrosative stress, and apoptosis [138], and antagonized cognitive impairment induced by feeding mice with a high fat [139] or high-cholesterol diet [140].

There is a lot of evidence showing that memory deficit is associated with impaired cerebral circulation and a decrease in the cholinergic system. It has been shown that quercetin protected the retina from apoptotic damage due to ischemia reperfusion injury in vivo [142] and was also neuroprotective in models of intracerebral hemorrhage in rats [141]. Tota et al., (2010) demonstrated that orally daily pre-treatment with quercetin $(2.5,5$ and $10 \mathrm{mg} / \mathrm{kg})$ showed a dose-dependent restoration of cerebral blood flow (CBF) and ATP content, significantly reduced by the administration of STZ $(0.5 \mathrm{mg} / \mathrm{kg})$ in mice. Further, quercetin prevented STZ-induced memory impairment and decreased AChE activity as well as oxidative and nitrosative stress, as evidenced by a significant decrease in MDA and nitrite, and increase in GSH levels [143]. Richetti et al., (2011) demonstrated the protective role of quercetin (single injection of $50 \mathrm{mg} / \mathrm{kg}$ concentration) against scopolamine-induced inhibitory avoidance memory deficits in zebrafish [144]. However, Nassiri-Asl (2013) observed that quercetin $(50 \mathrm{mg} / \mathrm{kg}$ ) could not be effective against oxidative stress in the hippocampus and 
cerebral cortex in kindled rats besides its anticonvulsant effects and protection against memory impairment [154].

Quercetin provided protection also against the neurotoxicity of several metals. Hu et al., (2008) evaluated the effect of quercetin on chronic lead $(\mathrm{Pb})$ exposure-induced impairment of synaptic plasticity in dentate gyrus (DG) area of rat hippocampus. The results showed that quercetin significantly increase the depressed input/output (I/O) functions, paired-pulse reactions (PPR) and long-term potentiation (LTP) of $\mathrm{Pb}$-exposed group. In addition, concentration of $\mathrm{Pb}$ in hippocampus was partially reduced after quercetin treatment [145]. Quercetin $(0.5-50 \mathrm{mg} / \mathrm{kg} / \mathrm{bw} /$ day $)$ protected also against DNA damage caused by exposure to methylmercury [146] and tungsten [147]. Several lines of evidences suggested that $\mathrm{Al}$ has severe toxic manifestations on the CNS. The research group of Sharma, found that pre-treatment with quercetin $(10 \mathrm{mg} / \mathrm{kg} / \mathrm{bw} /$ day $)$ before intragastrically administration of $\mathrm{Al}(10 \mathrm{mg} / \mathrm{kg} / \mathrm{bw} /$ day) decreased ROS levels, mitochondrial DNA oxidation and citrate synthase activity in both hippocampus and corpus striatum regions, while increased MnSOD activity of rat brain. In addition, quercetin prevented Al-induced translocation of cytochrome c (cyt-c), up-regulated Bcl-2, and down-regulated Bax, p53 and caspase-3 activation. It also reduced DNA fragmentation and increased the mitochondrial DNA copy number and mitochondrial content in the regions of rat brain [148-150].

Polychlorinated biphenyls (PCBs) are very toxic environmental contaminants known to trigger neurochemical damages and behavioral disorders. Bavithra et al. (2012) showed that quercetin acted as scavenger of the PCBs-induced free radicals and protected dopaminergic receptors in the cerebellum of rat [151]. Another study carried out by Selvakumar and coworkers (2013), evidenced that quercetin (50 mg/kg) suppresses ROS, enhances both enzymatic antioxidants and neurotransmitter levels and improves the cognitive functions damned by PCBs (2 mg/kg) [152]. Moreover, quercetin prevented alterations on cholinergic neurotransmission and in the behavioral tests also in rats experimentally demyelinated by ethidium bromide [153].

\subsection{Polymethoxiflavones}

In Table 5 are summarized the studies reporting the neuroprotective activity of Citrus polymethoxiflavones.

Table 5. Studies and experimental models of neurodegenerative diseases in which tangeretin or nobiletin were used.

\begin{tabular}{|c|c|c|c|}
\hline Polymethoxyflavones & Model & Disease/Condition & Reference \\
\hline \multirow{2}{*}{ tangeretin } & In vivo & 6-OHDA-injected rat & Datla et al., 2001 [155] \\
\hline & In vitro & LPS-stimulated microglia and BV-2 cells & Shu et al., 2014 [156] \\
\hline \multirow{10}{*}{ nobiletin } & In vitro & $A \beta_{1-42}$ or $A \beta_{1-40}$-exposed hippocampus neurons of rats & Matzukazi et al., 2006 [157] \\
\hline & In vivo & $\mathrm{A} \beta_{1-40}$-treated rats & 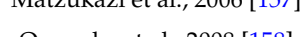 \\
\hline & In vivo & APP-SL 7-5 mice & Onozuka et al., 2008 [158] \\
\hline & In vivo & SAMP8 mice & Nakajima et al., 2013 [159] \\
\hline & In vivo & 3XTg-AD mice & Nakajima et al., 2015 [160] \\
\hline & In vivo & transgenic mice & Yamakuni et al., 2010 [161] \\
\hline & In vivo & $\mathrm{MPP}^{+}$- injected mice & Jeong et al., 2014 [162] \\
\hline & In vitro & LPS-treated BV-2 microglia cell & Cui et al., 2010 [163] \\
\hline & In vivo & cerebral ischemia inducted mice & Yamamoto et al., 2009 [164] \\
\hline & In vivo & cerebral ischemia inducted rats & Zhang et al., 2016 [165] \\
\hline
\end{tabular}

\subsubsection{Tangeretin}

Tangeretin is a polymethoxyflavone present exclusively in Citrus fruit peels. Neuroprotective effects of tangeretin were elucidated in an animal model of PD. Sub-chronic treatment of rats with tangeretin ( $20 \mathrm{mg} / \mathrm{kg} /$ day) for 4 days before 6-OHDA injection markedly reduced the loss of both $\mathrm{TH}^{+}$cells and striatal dopamine content evoked by unilateral infusion of 6-OHDA $(8 \mu \mathrm{g})$ onto medial forebrain bundle [155]. More recently, Shu and coworkers (2014) demonstrated that 
tangeretin suppressed microglial activation in the LPS-stimulated primary rat microglia and BV-2 cell culture [156] (Table 5).

\subsubsection{Nobiletin}

Nobiletin is a polymethoxylated flavone that is commonly presents in Citrus peels. Several papers reported the protective effect of nobiletin in different model of AD. Matsuzaki and coworkers (2006) observed that nobiletin $(10$ and $30 \mu \mathrm{M})$ reversed a reduction in the activity of CREB-phosphorylation by the sublethal concentration of $A \beta_{1-42}$ or $A \beta_{1-40}$ in cultured rat hippocampus neurons. Moreover, it ameliorated $\mathrm{A} \beta_{1-40}$-induced impairment of memory in $\mathrm{AD}$ model rats [157].

Onozuka and collaborators (2008) demonstrated that daily administrated nobiletin $(10 \mathrm{mg} / \mathrm{kg}$, i.p.) for 4 months reduced $A \beta$ plaque pathology and improved cognitive deficits in APP-SL 7-5 mice, a transgenic mouse model of AD [158]. More recently, the same authors showed that nobiletin (10-50 mg/ $\mathrm{kg} /$ day, i.p.) improved age-related cognitive impairment of senescence-accelerated mouse prone 8 (SAMP8) mice, and reduced both the oxidative stress and tau phosphorylation in their brain [159]. Moreover, they showed that nobiletin $(30 \mathrm{mg} / \mathrm{kg}$ ) administered for 3 months counteracted the impairment of short-term memory and recognition memory in a triple transgenic mouse model of $\mathrm{AD}$ (3XTg-AD mice). In addition, nobiletin reduced the levels of both soluble $A \beta_{1-40}$ and ROS in the brain and in the hippocampus of 3XTg-AD mice, respectively [160]. Furthermore, daily administration of nobiletin for four months rescued the memory impairment in fear conditioning, and decreased hippocampal A $\beta$ deposit in the transgenic mice [161].

The effect of nobiletin on neurological disorders was also evaluated in a neurotoxic model of PD. $\mathrm{MPP}^{+}$was unilaterally injected into the median forebrain bundle of rat brains with or without daily intraperitoneal injection of nobiletin $(1,10$ and $20 \mathrm{mg} / \mathrm{kg})$. The latter, at a dose of $10 \mathrm{mg} / \mathrm{kg}$, but not at 1 or $20 \mathrm{mg} / \mathrm{kg}$, significantly protected DA neurons in the substantia nigra of $\mathrm{MPP}^{+}$-treated rats, also reducing microglial activation [162]. The capability of nobiletin to suppress microgliosis was demonstrated also by the results of the study performed by Cui et al. (2010) [163]. They found that the polymethoxiflavone suppressed the activation of NF- $\mathrm{KB}$ signaling pathway and the release of NO, TNF- $\alpha$ and IL-1 $\beta$, as well as the phosphorylations of ERK, JNK and p-38 evoked by LPS in BV-2 microglia cells.

It is known that decreased cerebral blood flow causes cognitive impairments and neuronal injury in the progressive age-related neurodegenerative disorders such as AD and vascular dementia. Yamamoto et al., (2009) showed that treatment with $50 \mathrm{mg} / \mathrm{kg}$ of nobiletin (i.p.) for the consecutive 7 days before and after the induction of brain ischemia significantly inhibited delayed neuronal death in the hippocampal CA1 neurons and improved the contextual cerebral ischemia-induced memory deficits [164]. Very recently, Zhang et al. (2016) demonstrated that nobiletin (10 and $25 \mathrm{mg} / \mathrm{kg} /$ day; i.p.) administrated for 3 days prior to the experimental ischemia and immediately after surgery reduced brain edema and neurological deficit, as well as increased the expression of Nrf2, HO-1, SOD1 and GSH, while decreased the levels of NF-kB, MMP-9 and MDA [165].

\section{Conclusion Remarks and Future Perspectives}

During the last decades, several studies were performed to evaluate the neuroprotective effects of Citrus flavonoids and to identify their molecular targets. Literature data collected in our review support their protective activity in neuropathological conditions, especially in the presence of prooxidants or neurotoxins. These findings highlight the antioxidant nature of flavonoids, able to arrest free radical-induced oxidative damage, which is known to play a pivotal role in many degenerative diseases. Moreover, their neuroprotective action is mediated by the interaction with specific intracellular targets that are implicated in several signaling pathways important for maintaining the physiological status. In this way, Citrus flavonoids prevent the neuronal dysfunction due to both acute and chronic injuries in several in vivo experimental models. Nevertheless, the majority of studies on the beneficial effects of Citrus flavonoids have been performed in vitro and in vivo, without evidence from equivalent clinical 
trials. This means that in some cases, the experimental research on the neuroprotective effects of Citrus flavonoids does not take into account some aspects which are of great importance in clinical practice. For example, in some study, the pharmacological effect was observed at concentrations or dosages (in vitro and in vivo studies, respectively) of active substance which are unlikely to be reached in the clinical setting. Moreover, in some study it was used routes of administration that highly unlikely to be used by humans. Generally, a natural drug is orally administered (often as nutraceutical or dietary supplement), but bioavailability and presystemic elimination issues are often ignored by researchers. Consequently, the beneficial effects of orally administered flavonoids to improve or prevent CNS pathologies still remain an uncompleted debated topic. This because their poor absorption, rapid metabolism and selective permeability across the BBB limits their access to the CNS and, consequently, their neuroprotective efficacy. In other words, we do not know if the exciting preclinical results correspond to a real therapeutic success. This is the reason for their limited clinical application both alone and as an add-on therapy. Nevertheless, the development of novel natural compound-loaded delivery systems has improved the bioavailability of flavonoids together with their delivery to the brain, enhancing the potential of flavonoids as neuroprotective agents. Further studies are necessary to unravel more pharmacokinetics aspects of flavonoids, which in turn would be very important to stimulate well designed and well-controlled clinical trials confirming the excellent preclinical results.

Anyway, as suggested by this literature revision, we can consider Citrus flavonoids as key compounds for the development of a new generation of pharmacological agents effective in preventing and treating neurodegenerative diseases.

This review may be used as a starting point for novel nutraceuticals, food supplements or complementary and alternative drugs to maintain or improve the neurophysiological status.

Acknowledgments: This review has been written within the framework of the project "MEPRA" (PO FESR Sicilia 2007/2013, Linea d'Intervento 4.1.1.1, CUP G73F11000050004).

Author Contributions: Santa Cirmi performed the literature review and drafted the paper; Nadia Ferlazzo and Giovanni E. Lombardo and Elvira Ventura-Spagnolo helped in the collection of literature; Sebastiano Gangemi and Gioacchino Calapai revised the paper; Michele Navarra conceived and designed the study as well as assisted in writing the paper. All authors read and approved the manuscript.

Conflicts of Interest: The authors declare that there is no conflict of interests.

\section{References}

1. Perez-Hernandez, J.; Zaldivar-Machorro, V.J.; Villanueva-Porras, D.; Vega-Avila, E.; Chavarria, A. A potential alternative against neurodegenerative diseases: Phytodrugs. Oxid. Med. Cell. Longev. 2016, 2016, 8378613. [CrossRef] [PubMed]

2. Solanki, L.; Parihar, P.; Mansuri, M.L.; Parihar, M.S. Flavonoid-based therapies in the early management of neurodegenerative diseases. Adv. Nutr. 2015, 6, 64-72. [CrossRef] [PubMed]

3. Hwang, S.L.; Shih, P.H.; Yen, G.C. Neuroprotective effects of Citrus flavonoids. J. Agric. Food Chem. 2012, 60, 877-885. [CrossRef] [PubMed]

4. Manach, C.; Scalbert, A.; Morand, C.; Remesy, C.; Jimenez, L. Polyphenols: Food sources and bioavailability. Am. J. Clin. Nutr. 2004, 79, 727-747. [PubMed]

5. Middleton, E., Jr.; Kandaswami, C.; Theoharides, T.C. The effects of plant flavonoids on mammalian cells: Implications for inflammation, heart disease, and cancer. Pharmacol. Rev. 2000, 52, 673-751. [PubMed]

6. Kumar, S.; Pandey, A.K. Chemistry and biological activities of flavonoids: An overview. Sci. World J. 2013, 2013, 162750. [CrossRef] [PubMed]

7. Yao, L.H.; Jiang, Y.M.; Shi, J.; Tomas-Barberan, F.A.; Datta, N.; Singanusong, R.; Chen, S.S. Flavonoids in food and their health benefits. Plant Foods Hum. Nutr. 2004, 59, 113-122. [CrossRef] [PubMed]

8. Benavente-Garcia, O.; Castillo, J. Update on uses and properties of Citrus flavonoids: New findings in anticancer, cardiovascular, and anti-inflammatory activity. J. Agric. Food Chem. 2008, 56, 6185-6205. [CrossRef] [PubMed] 
9. Curro, M.; Risitano, R.; Ferlazzo, N.; Cirmi, S.; Gangemi, C.; Caccamo, D.; Ientile, R.; Navarra, M. Citrus bergamia juice extract attenuates $\beta$-amyloid-induced pro-inflammatory activation of thp- 1 cells through mapk and ap-1 pathways. Sci. Rep. 2016, 6, 20809. [CrossRef] [PubMed]

10. Ferlazzo, N.; Visalli, G.; Smeriglio, A.; Cirmi, S.; Lombardo, G.E.; Campiglia, P.; Di Pietro, A.; Navarra, M. Flavonoid fraction of orange and bergamot juices protect human lung epithelial cells from hydrogen peroxide-induced oxidative stress. Evid. Based Complement. Altern. Med. 2015, 2015, 957031. [CrossRef] [PubMed]

11. Ferlazzo, N.; Cirmi, S.; Russo, M.; Trapasso, E.; Ursino, M.R.; Lombardo, G.E.; Gangemi, S.; Calapai, G.; Navarra, M. NF- $\mathrm{kB}$ mediates the antiproliferative and proapoptotic effects of bergamot juice in HepG2 cells. Life Sci. 2016, 146, 81-91. [CrossRef] [PubMed]

12. Ferlazzo, N.; Visalli, G.; Cirmi, S.; Lombardo, G.E.; Lagana, P.; di Pietro, A.; Navarra, M. Natural iron chelators: Protective role in A549 cells of flavonoids-rich extracts of Citrus juices in $\mathrm{Fe}^{3+}$-induced oxidative stress. Environ. Toxicol. Pharmacol. 2016, 43, 248-256. [CrossRef] [PubMed]

13. Risitano, R.; Curro, M.; Cirmi, S.; Ferlazzo, N.; Campiglia, P.; Caccamo, D.; Ientile, R.; Navarra, M. Flavonoid fraction of bergamot juice reduces LPS-induced inflammatory response through SIRT1-mediated NF- $\mathrm{B}$ inhibition in THP-1 monocytes. PLoS ONE 2014, 9, e107431. [CrossRef] [PubMed]

14. Visalli, G.; Ferlazzo, N.; Cirmi, S.; Campiglia, P.; Gangemi, S.; di Pietro, A.; Calapai, G.; Navarra, M. Bergamot juice extract inhibits proliferation by inducing apoptosis in human colon cancer cells. Anti-Cancer Agents Med. Chem. 2014, 14, 1402-1413. [CrossRef]

15. Delle Monache, S.; Sanita, P.; Trapasso, E.; Ursino, M.R.; Dugo, P.; Russo, M.; Ferlazzo, N.; Calapai, G.; Angelucci, A.; Navarra, M. Mechanisms underlying the anti-tumoral effects of Citrus bergamia juice. PLoS ONE 2013, 8, e61484. [CrossRef] [PubMed]

16. Filocamo, A.; Bisignano, C.; Ferlazzo, N.; Cirmi, S.; Mandalari, G.; Navarra, M. In vitro effect of bergamot (Citrus bergamia) juice against caga-positive and-negative clinical isolates of helicobacter pylori. BMC Complement. Altern. Med. 2015, 15, 256. [CrossRef] [PubMed]

17. Impellizzeri, D.; Bruschetta, G.; di Paola, R.; Ahmad, A.; Campolo, M.; Cuzzocrea, S.; Esposito, E.; Navarra, M. The anti-inflammatory and antioxidant effects of bergamot juice extract (BJe) in an experimental model of inflammatory bowel disease. Clin. Nutr. 2015, 34, 1146-1154. [CrossRef] [PubMed]

18. Navarra, M.; Ursino, M.R.; Ferlazzo, N.; Russo, M.; Schumacher, U.; Valentiner, U. Effect of Citrus bergamia juice on human neuroblastoma cells in vitro and in metastatic xenograft models. Fitoterapia 2014, 95, 83-92. [CrossRef] [PubMed]

19. Celano, M.; Maggisano, V.; de Rose, R.F.; Bulotta, S.; Maiuolo, J.; Navarra, M.; Russo, D. Flavonoid fraction of Citrus reticulata juice reduces proliferation and migration of anaplastic thyroid carcinoma cells. Nutr. Cancer 2015, 67, 1183-1190. [CrossRef] [PubMed]

20. Marino, A.; Paterniti, I.; Cordaro, M.; Morabito, R.; Campolo, M.; Navarra, M.; Esposito, E.; Cuzzocrea, S. Role of natural antioxidants and potential use of bergamot in treating rheumatoid arthritis. PharmaNutrition 2015, 3, 53-59. [CrossRef]

21. Cirmi, S.; Bisignano, C.; Mandalari, G.; Navarra, M. Anti-infective potential of Citrus bergamia Risso et Poiteau (bergamot) derivatives: A systematic review. Phytother. Res. 2016, 30, 1404-1411. [CrossRef] [PubMed]

22. Impellizzeri, D.; Cordaro, M.; Campolo, M.; Gugliandolo, E.; Esposito, E.; Benedetto, F.; Cuzzocrea, S.; Navarra, M. Anti-inflammatory and antioxidant effects of flavonoid-rich fraction of bergamot juice (BJe) in a mouse model of intestinal ischemia/reperfusion injury. Front. Pharmacol. 2016, 30. [CrossRef] [PubMed]

23. Ferlazzo, N.; Cirmi, S.; Calapai, G.; Ventura-Spagnolo, E.; Gangemi, S.; Navarra, M. Anti-inflammatory activity of Citrus bergamia derivatives: Where do we stand? Molecules 2016, 21, 1273. [CrossRef] [PubMed]

24. Citraro, R.; Navarra, M.; Leo, A.; Donato di Paola, E.; Santangelo, E.; Lippiello, P.; Aiello, R.; Russo, E.; de Sarro, G. The anticonvulsant activity of a flavonoid-rich extract from orange juice involves both NMDA and GABA-benzodiazepine receptor complexes. Molecules 2016, 21, 1261. [CrossRef] [PubMed]

25. Fratiglioni, L.; Launer, L.J.; Andersen, K.; Breteler, M.M.; Copeland, J.R.; Dartigues, J.F.; Lobo, A.; Martinez-Lage, J.; Soininen, H.; Hofman, A. Incidence of dementia and major subtypes in europe: A collaborative study of population-based cohorts. Neurologic diseases in the elderly research group. Neurology 2000, 54, S10-S15. [PubMed]

26. O'Brien, R.J.; Wong, P.C. Amyloid precursor protein processing and Alzheimer's disease. Annu. Rev. Neurosci. 2011, 34, 185-204. [CrossRef] [PubMed] 
27. Sarkar, A.; Irwin, M.; Singh, A.; Riccetti, M.; Singh, A. Alzheimer's disease: The silver tsunami of the 21st century. Neural. Regen. Res. 2016, 11, 693-697. [PubMed]

28. Murphy, M.P.; LeVine, H., III. Alzheimer's disease and the amyloid- $\beta$ peptide. J. Alzheimers Dis. 2010, 19, 311-323. [PubMed]

29. Hong, H.; Kim, B.S.; Im, H.I. Pathophysiological role of neuroinflammation in neurodegenerative diseases and psychiatric disorders. Int. Neurourol. J. 2016, 20, S2-S7. [CrossRef] [PubMed]

30. Reeve, A.; Simcox, E.; Turnbull, D. Ageing and Parkinson's disease: Why is advancing age the biggest risk factor? Ageing Res. Rev. 2014, 14, 19-30. [CrossRef] [PubMed]

31. Wirdefeldt, K.; Adami, H.O.; Cole, P.; Trichopoulos, D.; Mandel, J. Epidemiology and etiology of Parkinson's disease: A review of the evidence. Eur. J. Epidemiol. 2011, 26, S1-S58. [CrossRef] [PubMed]

32. Norden, D.M.; Muccigrosso, M.M.; Godbout, J.P. Microglial priming and enhanced reactivity to secondary insult in aging, and traumatic cns injury, and neurodegenerative disease. Neuropharmacology 2015, 96, $29-41$. [CrossRef] [PubMed]

33. Cagnin, A.; Kassiou, M.; Meikle, S.R.; Banati, R.B. In vivo evidence for microglial activation in neurodegenerative dementia. Acta Neurol. Scand. Suppl. 2006, 185, 107-114. [CrossRef] [PubMed]

34. Ferrari, C.C.; Pott Godoy, M.C.; Tarelli, R.; Chertoff, M.; Depino, A.M.; Pitossi, F.J. Progressive neurodegeneration and motor disabilities induced by chronic expression of il- $1 \beta$ in the substantia nigra. Neurobiol. Dis. 2006, 24, 183-193. [CrossRef] [PubMed]

35. Novak, M.J.; Tabrizi, S.J. Huntington's disease. BMJ 2010, 340, c3109. [CrossRef] [PubMed]

36. Zhao, T.; Hong, Y.; Li, X.J.; Li, S.H. Subcellular clearance and accumulation of huntington disease protein: A mini-review. Front. Mol. Neurosci. 2016, 9, 27. [CrossRef] [PubMed]

37. Quarrell, O.; O'Donovan, K.L.; Bandmann, O.; Strong, M. The prevalence of juvenile huntington's disease: A review of the literature and meta-analysis. PLoS Curr. 2012, 4, e4f8606b742ef3. [CrossRef] [PubMed]

38. Rawlins, M.D.; Wexler, N.S.; Wexler, A.R.; Tabrizi, S.J.; Douglas, I.; Evans, S.J.; Smeeth, L. The prevalence of huntington's disease. Neuroepidemiology 2016, 46, 144-153. [CrossRef] [PubMed]

39. Wexler, N.S. Huntington's disease: Advocacy driving science. Annu. Rev Med. 2012, 63, 1-22. [CrossRef] [PubMed]

40. Hannan, A.J. Novel therapeutic targets for huntington's disease. Expert. Opin. Ther. Targets 2005, 9, 639-650. [CrossRef] [PubMed]

41. Ross, C.A.; Aylward, E.H.; Wild, E.J.; Langbehn, D.R.; Long, J.D.; Warner, J.H.; Scahill, R.I.; Leavitt, B.R.; Stout, J.C.; Paulsen, J.S.; et al. Huntington disease: Natural history, biomarkers and prospects for therapeutics. Nat. Rev. Neurol. 2014, 10, 204-216. [CrossRef] [PubMed]

42. Chen, C.; Dong, X.P. Epidemiological characteristics of human prion diseases. Infect. Dis. Poverty 2016, 5, 47. [CrossRef] [PubMed]

43. Prusiner, S.B. Prions. Proc. Natl. Acad. Sci. USA 1998, 95, 13363-13383. [CrossRef] [PubMed]

44. National Clinical Guideline Centre (UK). Motor Neurone Disease: Assessment and Management; National Institute for Health and Care Excellence (UK): London, UK, 2016; No. 42.

45. Balendra, R.; Patani, R. Quo vadis motor neuron disease? World J. Methodol. 2016, 6, 56-64. [CrossRef] [PubMed]

46. Madill, M.; Fitzgerald, D.; O'Connell, K.E.; Dev, K.K.; Shen, S.; FitzGerald, U. In vitro and ex vivo models of multiple sclerosis. Drug Discov. Today 2016. [CrossRef] [PubMed]

47. Watad, A.; Azrielant, S.; Soriano, A.; Bracco, D.; Abu Much, A.; Amital, H. Association between seasonal factors and multiple sclerosis. Eur. J. Epidemiol. 2016. [CrossRef] [PubMed]

48. Food and Agricultural Organization of the United Nations. Available online: http://www.fao.org/docrep/ 006/y5143e/y5143e12.htm (accessed on 28 September 2016).

49. Castillo, J.; Benavente, O.; Delrio, J.A. Naringin and neohesperidin levels during development of leaves, flower buds, and fruits of Citrus-aurantium. Plant Physiol. 1992, 99, 67-73. [CrossRef] [PubMed]

50. Jiang, N.; Doseff, A.I.; Grotewold, E. Flavones: From biosynthesis to health benefits. Plants 2016, 5, 27. [CrossRef] [PubMed]

51. Leem, E.; Nam, J.H.; Jeon, M.T.; Shin, W.H.; Won, S.Y.; Park, S.J.; Choi, M.S.; Jin, B.K.; Jung, U.J.; Kim, S.R. Naringin protects the nigrostriatal dopaminergic projection through induction of gdnf in a neurotoxin model of Parkinson's disease. J. Nutr. Biochem. 2014, 25, 801-806. [CrossRef] [PubMed] 
52. Kim, H.D.; Jeong, K.H.; Jung, U.J.; Kim, S.R. Naringin treatment induces neuroprotective effects in a mouse model of Parkinson's disease in vivo, but not enough to restore the lesioned dopaminergic system. J. Nutr. Biochem. 2016, 28, 140-146. [CrossRef] [PubMed]

53. Gopinath, K.; Sudhandiran, G. Naringin modulates oxidative stress and inflammation in 3-nitropropionic acid-induced neurodegeneration through the activation of nuclear factor-erythroid 2-related factor-2 signalling pathway. Neuroscience 2012, 227, 134-143. [CrossRef] [PubMed]

54. Prakash, A.; Shur, B.; Kumar, A. Naringin protects memory impairment and mitochondrial oxidative damage against aluminum-induced neurotoxicity in rats. Int. J. Neurosci. 2013, 123, 636-645. [CrossRef] [PubMed]

55. Kumar, A.; Dogra, S.; Prakash, A. Protective effect of naringin, a Citrus flavonoid, against colchicine-induced cognitive dysfunction and oxidative damage in rats. J. Med. Food 2010, 13, 976-984. [CrossRef] [PubMed]

56. Antunes, M.S.; Goes, A.T.R.; Boeira, S.P.; Prigol, M.; Jesse, C.R. Protective effect of hesperidin in a model of Parkinson's disease induced by 6-hydroxydopamine in aged mice. Nutrition 2014, 30, 1415-1422. [CrossRef] [PubMed]

57. Menze, E.T.; Tadros, M.G.; Abdel-Tawab, A.M.; Khalifa, A.E. Potential neuroprotective effects of hesperidin on 3-nitropropionic acid-induced neurotoxicity in rats. Neurotoxicology 2012, 33, 1265-1275. [CrossRef] [PubMed]

58. Li, C.Y.; Zug, C.; Qu, H.C.; Schluesener, H.; Zhang, Z.Y. Hesperidin ameliorates behavioral impairments and neuropathology of transgenic APP/PS1 mice. Behav. Brain Res. 2015, 281, 32-42. [CrossRef] [PubMed]

59. Wang, D.M.; Liu, L.; Zhu, X.Y.; Wu, W.L.; Wang, Y. Hesperidin alleviates cognitive impairment, mitochondrial dysfunction and oxidative stress in a mouse model of Alzheimer's disease. Cell. Mol. Neurobiol. 2014, 34, 1209-1221. [CrossRef] [PubMed]

60. Javed, H.; Vaibhav, K.; Ahmed, M.E.; Khan, A.; Tabassum, R.; Islam, F.; Safhi, M.M.; Islam, F. Effect of hesperidin on neurobehavioral, neuroinflammation, oxidative stress and lipid alteration in intracerebroventricular streptozotocin induced cognitive impairment in mice. J. Neurol. Sci. 2015, 348, 51-59. [CrossRef] [PubMed]

61. Thenmozhi, A.J.; Raja, T.R.W.; Janakiraman, U.; Manivasagam, T. Neuroprotective effect of hesperidin on aluminium chloride induced Alzheimer's disease in wistar rats. Neurochem. Res. 2015, 40, 767-776. [CrossRef] [PubMed]

62. Justin Thenmozhi, A.; William Raja, T.R.; Manivasagam, T.; Janakiraman, U.; Mohamed Essa, M. Hesperidin ameliorates cognitive dysfunction, oxidative stress and apoptosis against aluminium chloride induced rat model of Alzheimer's disease. Nutr. Neurosci. 2016. [CrossRef] [PubMed]

63. Chang, C.Y.; Lin, T.Y.; Lu, C.W.; Huang, S.K.; Wang, Y.C.; Chou, S.S.P.; Wang, S.J. Hesperidin inhibits glutamate release and exerts neuroprotection against excitotoxicity induced by kainic acid in the hippocampus of rats. Neurotoxicology 2015, 50, 157-169. [CrossRef] [PubMed]

64. Choi, E.J.; Ahn, W.S. Neuroprotective effects of chronic hesperetin administration in mice. Arch. Pharm. Res. 2008, 31, 1457-1462. [CrossRef] [PubMed]

65. Kiasalari, Z.; Khalili, M.; Baluchnejadmojarad, T.; Roghani, M. Protective effect of oral hesperetin against unilateral striatal 6-hydroxydopamine damage in the rat. Neurochem. Res. 2016, 41, 1065-1072. [CrossRef] [PubMed]

66. Rainey-Smith, S.; Schroetke, L.W.; Bahia, P.; Fahmi, A.; Skilton, R.; Spencer, J.P.; Rice-Evans, C.; Rattray, M.; Williams, R.J. Neuroprotective effects of hesperetin in mouse primary neurones are independent of creb activation. Neurosci. Lett. 2008, 438, 29-33. [CrossRef] [PubMed]

67. Vauzour, D.; Vafeiadou, K.; Rice-Evans, C.; Williams, R.J.; Spencer, J.P. Activation of pro-survival AKT and ERK1/2 signalling pathways underlie the anti-apoptotic effects of flavanones in cortical neurons. J. Neurochem. 2007, 103, 1355-1367. [CrossRef] [PubMed]

68. Hwang, S.L.; Yen, G.C. Neuroprotective effects of the Citrus flavanones against $\mathrm{H}_{2} \mathrm{O}_{2}$-induced cytotoxicity in PC12 cells. J. Agric. Food Chem. 2008, 56, 859-864. [CrossRef] [PubMed]

69. Khan, M.B.; Khan, M.M.; Khan, A.; Ahmed, M.E.; Ishrat, T.; Tabassum, R.; Vaibhav, K.; Ahmad, A.; Islam, F. Naringenin ameliorates Alzheimer's disease (AD)-type neurodegeneration with cognitive impairment (AD-TNDCI) caused by the intracerebroventricular-streptozotocin in rat model. Neurochem. Int. 2012, 61, 1081-1093. [CrossRef] [PubMed]

70. Baluchnejadmojarad, T.; Roghani, M. Effect of naringenin on intracerebroventricular streptozotocin-induced cognitive deficits in rat: A behavioral analysis. Pharmacology 2006, 78, 193-197. [CrossRef] [PubMed] 
71. Heo, H.J.; Kim, D.O.; Shin, S.C.; Kim, M.J.; Kim, B.G.; Shin, D.H. Effect of antioxidant flavanone, naringenin, from Citrus junos on neuroprotection. J. Agric. Food Chem. 2004, 52, 1520-1525. [CrossRef] [PubMed]

72. Wu, L.H.; Lin, C.; Lin, H.Y.; Liu, Y.S.; Wu, C.Y.J.; Tsai, C.F.; Chang, P.C.; Yeh, W.L.; Lu, D.Y. Naringenin suppresses neuroinflammatory responses through inducing suppressor of cytokine signaling 3 expression. Mol. Neurobiol. 2016, 53, 1080-1091. [CrossRef] [PubMed]

73. Vafeiadou, K.; Vauzour, D.; Lee, H.Y.; Rodriguez-Mateos, A.; Williams, R.J.; Spencer, J.P. The Citrus flavanone naringenin inhibits inflammatory signalling in glial cells and protects against neuroinflammatory injury. Arch. Biochem. Biophys. 2009, 484, 100-109. [CrossRef] [PubMed]

74. Morelli, S.; Piscioneri, A.; Salerno, S.; Al-Fageeh, M.B.; Drioli, E.; de Bartolo, L. Neuroprotective effect of didymin on hydrogen peroxide-induced injury in the neuronal membrane system. Cells Tissues Organs 2014, 199, 184-200. [CrossRef] [PubMed]

75. Choi, B.S.; Sapkota, K.; Kim, S.; Lee, H.J.; Choi, H.S.; Kim, S.J. Antioxidant activity and protective effects of Tripterygium regelii extract on hydrogen peroxide-induced injury in human dopaminergic cells, SH-SY5Y. Neurochem. Res. 2010, 35, 1269-1280. [CrossRef] [PubMed]

76. Rong, W.; Wang, J.; Liu, X.; Jiang, L.; Wei, F.; Hu, X.; Han, X.; Liu, Z. Naringin treatment improves functional recovery by increasing bdnf and vegf expression, inhibiting neuronal apoptosis after spinal cord injury. Neurochem. Res. 2012, 37, 1615-1623. [CrossRef] [PubMed]

77. Golechha, M.; Chaudhry, U.; Bhatia, J.; Saluja, D.; Arya, D.S. Naringin protects against kainic acid-induced status epilepticus in rats: Evidence for an antioxidant, anti-inflammatory and neuroprotective intervention. Biol. Pharm. Bull. 2011, 34, 360-365. [CrossRef] [PubMed]

78. Brouillet, E.; Jacquard, C.; Bizat, N.; Blum, D. 3-Nitropropionic acid: A mitochondrial toxin to uncover physiopathological mechanisms underlying striatal degeneration in huntington's disease. J. Neurochem. 2005, 95, 1521-1540. [CrossRef] [PubMed]

79. Parhiz, H.; Roohbakhsh, A.; Soltani, F.; Rezaee, R.; Iranshahi, M. Antioxidant and anti-inflammatory properties of the Citrus flavonoids hesperidin and hesperetin: An updated review of their molecular mechanisms and experimental models. Phytother. Res. 2015, 29, 323-331. [CrossRef] [PubMed]

80. Youdim, K.A.; Dobbie, M.S.; Kuhnle, G.; Proteggente, A.R.; Abbott, N.J.; Rice-Evans, C. Interaction between flavonoids and the blood-brain barrier: In vitro studies. J. Neurochem. 2003, 85, 180-192. [CrossRef] [PubMed]

81. Herrmann, N.; Chau, S.A.; Kircanski, I.; Lanctot, K.L. Current and emerging drug treatment options for Alzheimer's disease a systematic review. Drugs 2011, 71, 2031-2065. [CrossRef] [PubMed]

82. Chin-Chan, M.; Navarro-Yepes, J.; Quintanilla-Vega, B. Environmental pollutants as risk factors for neurodegenerative disorders: Alzheimer and Parkinson diseases. Front. Cell. Neurosci. 2015, 9, 124. [CrossRef] [PubMed]

83. Mehta, A.; Prabhakar, M.; Kumar, P.; Deshmukh, R.; Sharma, P.L. Excitotoxicity: Bridge to various triggers in neurodegenerative disorders. Eur. J. Pharmacol. 2013, 698, 6-18. [CrossRef] [PubMed]

84. Lau, A.; Tymianski, M. Glutamate receptors, neurotoxicity and neurodegeneration. Pflug. Arch. Eur. J. Phy. 2010, 460, 525-542. [CrossRef] [PubMed]

85. De la Monte, S.M.; Tong, M. Mechanisms of nitrosamine-mediated neurodegeneration: Potential relevance to sporadic Alzheimer's disease. J. Alzheimers Dis. 2009, 17, 817-825. [PubMed]

86. Lester-Coll, N.; Rivera, E.J.; Soscia, S.J.; Doiron, K.; Wands, J.R.; de la Monte, S.M. Intracerebral streptozotocin model of type 3 diabetes: Relevance to sporadic Alzheimer's disease. J. Alzheimers Dis. 2006, 9, 13-33. [PubMed]

87. Choi, A.Y.; Choi, J.H.; Lee, J.Y.; Yoon, K.S.; Choe, W.; Ha, J.; Yeo, E.J.; Kang, I. Apigenin protects HT22 murine hippocampal neuronal cells against endoplasmic reticulum stress-induced apoptosis. Neurochem. Int. 2010, 57, 143-152. [CrossRef] [PubMed]

88. Braidy, N.; Grant, R.; Adams, S.; Guillemin, G.J. Neuroprotective effects of naturally occurring polyphenols on quinolinic acid-induced excitotoxicity in human neurons. FEBS J. 2010, 277, 368-382. [CrossRef] [PubMed]

89. Losi, G.; Puia, G.; Garzon, G.; de Vuono, M.C.; Baraldi, M. Apigenin modulates gabaergic and glutamatergic transmission in cultured cortical neurons. Eur. J. Pharmacol. 2004, 502, 41-46. [CrossRef] [PubMed]

90. Zhao, L.; Wang, J.L.; Liu, R.; Li, X.X.; Li, J.F.; Zhang, L. Neuroprotective, anti-amyloidogenic and neurotrophic effects of apigenin in an Alzheimer's disease mouse model. Molecules 2013, 18, 9949-9965. [CrossRef] [PubMed] 
91. Liu, R.; Zhang, T.T.; Yang, H.G.; Lan, X.; Ying, J.A.; Du, G.H. The flavonoid apigenin protects brain neurovascular coupling against amyloid- $\beta(25-35)$-induced toxicity in mice. J. Alzheimers Dis. 2011, 24, 85-100. [PubMed]

92. Popovic, M.; Caballero-Bleda, M.; Benavente-Garcia, O.; Castillo, J. The flavonoid apigenin delays forgetting of passive avoidance conditioning in rats. J. Psychopharmacol. 2014, 28, 498-501. [CrossRef] [PubMed]

93. Taupin, P. Apigenin and related compounds stimulate adult neurogenesis. Mars, inc., the salk institute for biological studies: Wo2008147483. Expert Opin Ther. Pat. 2009, 19, 523-527. [CrossRef] [PubMed]

94. Patil, C.S.; Singh, V.P.; Satyanarayan, P.S.V.; Jain, N.K.; Singh, A.; Kulkarni, S.K. Protective effect of flavonoids against aging- and lipopolysaccharide-induced cognitive impairment in mice. Pharmacology 2003, 69, 59-67. [CrossRef] [PubMed]

95. Patil, S.P.; Jain, P.D.; Sancheti, J.S.; Ghumatkar, P.J.; Tambe, R.; Sathaye, S. Neuroprotective and neurotrophic effects of apigenin and luteolin in mptp induced Parkinsonism in mice. Neuropharmacology 2014, 86, 192-202. [CrossRef] [PubMed]

96. Liu, W.H.; Kong, S.Z.; Xie, Q.F.; Su, J.Y.; Li, W.J.; Guo, H.Z.; Li, S.S.; Feng, X.X.; Su, Z.R.; Xu, Y.; et al. Protective effects of apigenin against 1-methyl-4-phenylpyridinium ion-induced neurotoxicity in PC12 cells. Int. J. Mol. Med. 2015, 35, 739-746. [CrossRef] [PubMed]

97. Wu, P.S.; Yen, J.H.; Kou, M.C.; Wu, M.J. Luteolin and apigenin attenuate 4-hydroxy-2-nonenal-mediated cell death through modulation of UPR, Nrf2-ARE and MAPK pathways in PC12 cells. PLoS ONE 2015, 10, e0130599. [CrossRef] [PubMed]

98. Fu, X.B.; Zhang, J.Z.; Guo, L.; Xu, Y.G.; Sun, L.Y.; Wang, S.S.; Feng, Y.; Gou, L.S.; Zhang, L.; Liu, Y. Protective role of luteolin against cognitive dysfunction induced by chronic cerebral hypoperfusion in rats. Pharmacol. Biochem. Behav. 2014, 126, 122-130. [CrossRef] [PubMed]

99. Xu, B.; Li, X.X.; He, G.R.; Hu, J.J.; Mu, X.; Tian, S.; Du, G.H. Luteolin promotes long-term potentiation and improves cognitive functions in chronic cerebral hypoperfused rats. Eur. J. Pharmacol. 2010, 627, 99-105. [CrossRef] [PubMed]

100. Liu, Y.; Fu, X.B.; Lan, N.; Li, S.; Zhang, J.Z.; Wang, S.S.; Li, C.; Shang, Y.G.; Huang, T.H.; Zhang, L. Luteolin protects against high fat diet-induced cognitive deficits in obesity mice. Behav. Brain Res. 2014, 267, 178-188. [CrossRef] [PubMed]

101. Wang, H.M.; Wang, H.L.; Cheng, H.X.; Che, Z.Y. Ameliorating effect of luteolin on memory impairment in an Alzheimer's disease model. Mol. Med. Rep. 2016, 13, 4215-4220. [CrossRef] [PubMed]

102. Hu, L.W.; Yen, J.H.; Shen, Y.T.; Wu, K.Y.; Wu, M.J. Luteolin modulates 6-hydroxydopamine-induced transcriptional changes of stress response pathways in PC12 cells. PLoS ONE 2014, 9, e97880. [CrossRef] [PubMed]

103. Wruck, C.J.; Claussen, M.; Fuhrmann, G.; Romer, L.; Schulz, A.; Pufe, T.; Waetzig, V.; Peipp, M.; Herdegen, T.; Gotz, M.E. Luteolin protects rat PC12 and C6 cells against MPP ${ }^{+}$induced toxicity via an ERK dependent Keapl-Nrf2-ARE pathway. J. Neural. Transm. Suppl. 2007, 72, 57-67. [PubMed]

104. Rezai-Zadeh, K.; Ehrhart, J.; Bai, Y.; Sanberg, P.R.; Bickford, P.; Tan, J.; Shytle, R.D. Apigenin and luteolin modulate microglial activation via inhibition of STAT1-induced CD40 expression. J. Neuroinflamm. 2008, 5. [CrossRef] [PubMed]

105. Rezai-Zadeh, K.; Shytle, R.D.; Bai, Y.; Tian, J.; Hou, H.Y.; Mori, T.; Zeng, J.; Obregon, D.; Town, T.; Tan, J. Flavonoid-mediated presenilin-1 phosphorylation reduces Alzheimer's disease $\beta$-amyloid production. J. Cell. Mol. Med. 2009, 13, 574-588. [CrossRef] [PubMed]

106. Kao, T.K.; Ou, Y.C.; Lin, S.Y.; Pan, H.C.; Song, P.J.; Raung, S.L.; Lai, C.Y.; Liao, S.L.; Lu, H.C.; Chen, C.J. Luteolin inhibits cytokine expression in endotoxin/cytokine-stimulated microglia. J. Nutr. Biochem. 2011, 22, 612-624. [CrossRef] [PubMed]

107. Chen, H.Q.; Jin, Z.Y.; Wang, X.J.; Xua, X.M.; Deng, L.; Zhao, J.W. Luteolin protects dopaminergic neurons from inflammation-induced injury through inhibition of microglial activation. Neurosci. Lett. 2008, 448, 175-179. [CrossRef] [PubMed]

108. Zhu, L.H.; Bi, W.; Qi, R.B.; Wang, H.D.; Lu, D.X. Luteolin inhibits microglial inflammation and improves neuron survival against inflammation. Int. J. Neurosci. 2011, 121, 329-336. [CrossRef] [PubMed] 
109. Zhu, L.H.; Bi, W.; Lu, D.; Zhang, C.J.; Shu, X.M.; Lu, D.X. Luteolin inhibits SH-SY5Y cell apoptosis through suppression of the nuclear transcription factor- $\mathrm{k} B$, mitogen-activated protein kinase and protein kinase B pathways in lipopolysaccharide-stimulated cocultured BV2 cells. Exp. Ther. Med. 2014, 7, 1065-1070. [CrossRef] [PubMed]

110. Dirscherl, K.; Karlstetter, M.; Ebert, S.; Kraus, D.; Hlawatsch, J.; Walczak, Y.; Moehle, C.; Fuchshofer, R.; Langmann, T. Luteolin triggers global changes in the microglial transcriptome leading to a unique anti-inflammatory and neuroprotective phenotype. J. Neuroinflamm. 2010, 7. [CrossRef] [PubMed]

111. Nabavi, S.F.; Braidy, N.; Gortzi, O.; Sobarzo-Sanchez, E.; Daglia, M.; Skalicka-Wozniak, K.; Nabavi, S.M. Luteolin as an anti-inflammatory and neuroprotective agent: A brief review. Brain Res. Bull. 2015, 119, 1-11. [CrossRef] [PubMed]

112. Chao, C.C.; Hu, S.X. Tumor-necrosis-factor-alpha potentiates glutamate neurotoxicity in human fetal brain-cell cultures. Dev. Neurosci. 1994, 16, 172-179. [CrossRef] [PubMed]

113. Le, W.D.; Rowe, D.; Xie, W.J.; Ortiz, I.; He, Y.; Appel, S.H. Microglial activation and dopaminergic cell injury: An in vitro model relevant to Parkinson's disease. J. Neurosci. 2001, 21, 8447-8455. [PubMed]

114. Park, S.E.; Sapkota, K.; Kim, S.; Kim, H.; Kim, S.J. Kaempferol acts through mitogen-activated protein kinases and protein kinase B/AKT to elicit protection in a model of neuroinflammation in BV2 microglial cells. Br. J. Pharmacol. 2011, 164, 1008-1025. [CrossRef] [PubMed]

115. Yang, E.J.; Kim, G.S.; Jun, M.; Song, K.S. Kaempferol attenuates the glutamate-induced oxidative stress in mouse-derived hippocampal neuronal HT22 cells. Food Funct. 2014, 5, 1395-1402. [CrossRef] [PubMed]

116. Magalingam, K.B.; Radhakrishnan, A.; Haleagrahara, N. Rutin, a bioflavonoid antioxidant protects rat pheochromocytoma (PC-12) cells against 6-hydroxydopamine (6-OHDA)-induced neurotoxicity. Int. J. Mol. Med. 2013, 32, 235-240. [PubMed]

117. Song, K.; Kim, S.; Na, J.Y.; Park, J.H.; Kim, J.K.; Kim, J.H.; Kwon, J. Rutin attenuates ethanol-induced neurotoxicity in hippocampal neuronal cells by increasing aldehyde dehydrogenase 2. Food Chem. Toxicol. 2014, 72, 228-233. [CrossRef] [PubMed]

118. Yu, X.L.; Li, Y.N.; Zhang, H.; Su, Y.J.; Zhou, W.W.; Zhang, Z.P.; Wang, S.W.; Xu, P.X.; Wang, Y.J.; Liu, R.T. Rutin inhibits amylin-induced neurocytotoxicity and oxidative stress. Food Funct. 2015, 6, 3296-3306. [CrossRef] [PubMed]

119. Na, J.Y.; Kim, S.; Song, K.; Kwon, J. Rutin alleviates prion peptide-induced cell death through inhibiting apoptotic pathway activation in dopaminergic neuronal cells. Cell. Mol. Neurobiol. 2014, 34, 1071-1079. [CrossRef] [PubMed]

120. Nassiri-Asl, M.; Naserpour Farivar, T.; Abbasi, E.; Sadeghnia, H.R.; Sheikhi, M.; Lotfizadeh, M.; Bazahang, P. Effects of rutin on oxidative stress in mice with kainic acid-induced seizure. J. Integr. Med. 2013, 11, 337-342. [CrossRef] [PubMed]

121. Khan, M.M.; Raza, S.S.; Javed, H.; Ahmad, A.; Khan, A.; Islam, F.; Safhi, M.M.; Islam, F. Rutin protects dopaminergic neurons from oxidative stress in an animal model of Parkinson's disease. Neurotox. Res. 2012, 22, 1-15. [CrossRef] [PubMed]

122. Wang, S.W.; Wang, Y.J.; Su, Y.J.; Zhou, W.W.; Yang, S.G.; Zhang, R.; Zhao, M.; Li, Y.N.; Zhang, Z.P.; Zhan, D.W.; et al. Rutin inhibits $\beta$-amyloid aggregation and cytotoxicity, attenuates oxidative stress, and decreases the production of nitric oxide and proinflammatory cytokines. Neurotoxicology 2012, 33, 482-490. [CrossRef] [PubMed]

123. Xu, P.X.; Wang, S.W.; Yu, X.L.; Su, Y.J.; Wang, T.; Zhou, W.W.; Zhang, H.; Wang, Y.J.; Liu, R.T. Rutin improves spatial memory in Alzheimer's disease transgenic mice by reducing abeta oligomer level and attenuating oxidative stress and neuroinflammation. Behav. Brain Res. 2014, 264, 173-180. [CrossRef] [PubMed]

124. Machawal, L.; Kumar, A. Possible involvement of nitric oxide mechanism in the neuroprotective effect of rutin against immobilization stress induced anxiety like behaviour, oxidative damage in mice. Pharmacol. Rep. 2014, 66, 15-21. [CrossRef] [PubMed]

125. Moghbelinejad, S.; Nassiri-Asl, M.; Farivar, T.N.; Abbasi, E.; Sheikhi, M.; Taghiloo, M.; Farsad, F.; Samimi, A.; Hajiali, F. Rutin activates the MAPK pathway and BDNF gene expression on beta-amyloid induced neurotoxicity in rats. Toxicol. Lett. 2014, 224, 108-113. [CrossRef] [PubMed]

126. Habtemariam, S. Rutin as a natural therapy for Alzheimer's disease: Insights into its mechanisms of action. Curr. Med. Chem. 2016, 23, 860-873. [CrossRef] [PubMed] 
127. Jesberger, J.A.; Richardson, J.S. Oxygen free-radicals and brain-dysfunction. Int. J. Neurosci. 1991, 57, 1-17. [CrossRef] [PubMed]

128. Shin, H.J.; Lee, J.Y.; Son, E.; Lee, D.H.; Kim, H.J.; Kang, S.S.; Cho, G.J.; Choi, W.S.; Roh, G.S. Curcumin attenuates the kainic acid-induced hippocampal cell death in the mice. Neurosci. Lett. 2007, 416, 49-54. [CrossRef] [PubMed]

129. Suematsu, N.; Hosoda, M.; Fujimori, K. Protective effects of quercetin against hydrogen peroxide-induced apoptosis in human neuronal SH-SY5Y cells. Neurosci. Lett. 2011, 504, 223-227. [CrossRef] [PubMed]

130. Roshanzamir, F.; Yazdanparast, R. Quercetin attenuates cell apoptosis of oxidant-stressed SK-N-MC cells while suppressing up-regulation of the defensive element, HIF-1 $\alpha$. Neuroscience 2014, 277, 780-793. [CrossRef] [PubMed]

131. Jembrek, M.J.; Vukovic, L.; Puhovic, J.; Erhardt, J.; Orsolic, N. Neuroprotective effect of quercetin against hydrogen peroxide-induced oxidative injury in P19 neurons. J. Mol. Neurosci. 2012, 47, 286-299. [CrossRef] [PubMed]

132. Sajad, M.; Zargan, J.; Zargar, M.A.; Sharma, J.; Umar, S.; Arora, R.; Khan, H.A. Quercetin prevents protein nitration and glycolytic block of proliferation in hydrogen peroxide insulted cultured neuronal precursor cells (NPCS): Implications on cns regeneration. Neurotoxicology 2013, 36, 24-33. [CrossRef] [PubMed]

133. Ansari, M.A.; Abdul, H.M.; Joshi, G.; Opii, W.O.; Butterfield, D.A. Protective effect of quercetin in primary neurons against A $\beta$ (1-42): Relevance to Alzheimer's disease. J. Nutr. Biochem. 2009, 20, 269-275. [CrossRef] [PubMed]

134. Zhang, X.; Hu, J.; Zhong, L.; Wang, N.; Yang, L.; Liu, C.C.; Li, H.; Wang, X.; Zhou, Y.; Zhang, Y.; et al. Quercetin stabilizes apolipoprotein E and reduces brain A $\beta$ levels in amyloid model mice. Neuropharmacology 2016, 108, 179-192. [CrossRef] [PubMed]

135. Lv, C.; Hong, T.; Yang, Z.; Zhang, Y.; Wang, L.; Dong, M.; Zhao, J.; Mu, J.; Meng, Y. Effect of quercetin in the 1-methyl-4-phenyl-1,2,3,6-tetrahydropyridine-induced mouse model of Parkinson's disease. Evid. Based Complement. Altern. Med. 2012, 2012, 928643. [CrossRef] [PubMed]

136. Chen, J.C.; Ho, F.M.; Pei-Dawn Lee, C.; Chen, C.P.; Jeng, K.C.; Hsu, H.B.; Lee, S.T.; Wen Tung, W.; Lin, W.W. Inhibition of iNOS gene expression by quercetin is mediated by the inhibition of IкB kinase, nuclear factor-kappa B and STAT1, and depends on heme oxygenase-1 induction in mouse Bv-2 microglia. Eur. J. Pharmacol. 2005, 521, 9-20. [CrossRef] [PubMed]

137. Kang, C.H.; Choi, Y.H.; Moon, S.K.; Kim, W.J.; Kim, G.Y. Quercetin inhibits lipopolysaccharide-induced nitric oxide production in BV2 microglial cells by suppressing the NF- $\mathrm{B}$ pathway and activating the Nrf2-dependent HO-1 pathway. Int. Immunopharmacol. 2013, 17, 808-813. [CrossRef] [PubMed]

138. Bournival, J.; Francoeur, M.A.; Renaud, J.; Martinoli, M.G. Quercetin and sesamin protect neuronal PC12 cells from high-glucose-induced oxidation, nitrosative stress, and apoptosis. Rejuvenation Res. 2012, 15, 322-333. [CrossRef] [PubMed]

139. Xia, S.F.; Xie, Z.X.; Qiao, Y.; Li, L.R.; Cheng, X.R.; Tang, X.; Shi, Y.H.; Le, G.W. Differential effects of quercetin on hippocampus-dependent learning and memory in mice fed with different diets related with oxidative stress. Physiol. Behav. 2015, 138, 325-331. [CrossRef] [PubMed]

140. Lu, J.; Wu, D.M.; Zheng, Y.L.; Hu, B.; Zhang, Z.F.; Shan, Q.; Zheng, Z.H.; Liu, C.M.; Wang, Y.J. Quercetin activates AMP-activated protein kinase by reducing PP2C expression protecting old mouse brain against high cholesterol-induced neurotoxicity. J. Pathol. 2010, 222, 199-212. [CrossRef] [PubMed]

141. Zhang, Y.; Yi, B.; Ma, J.; Zhang, L.; Zhang, H.; Yang, Y.; Dai, Y. Quercetin promotes neuronal and behavioral recovery by suppressing inflammatory response and apoptosis in a rat model of intracerebral hemorrhage. Neurochem. Res. 2015, 40, 195-203. [CrossRef] [PubMed]

142. Arikan, S.; Ersan, I.; Karaca, T.; Kara, S.; Gencer, B.; Karaboga, I.; Hasan Ali, T. Quercetin protects the retina by reducing apoptosis due to ischemia-reperfusion injury in a rat model. Arq. Bras. Oftalmol. 2015, 78, 100-104. [CrossRef] [PubMed]

143. Tota, S.; Awasthi, H.; Kamat, P.K.; Nath, C.; Hanif, K. Protective effect of quercetin against intracerebral streptozotocin induced reduction in cerebral blood flow and impairment of memory in mice. Behav. Brain Res. 2010, 209, 73-79. [CrossRef] [PubMed]

144. Richetti, S.K.; Blank, M.; Capiotti, K.M.; Piato, A.L.; Bogo, M.R.; Vianna, M.R.; Bonan, C.D. Quercetin and rutin prevent scopolamine-induced memory impairment in zebrafish. Behav. Brain Res. 2011, 217, 10-15. [CrossRef] [PubMed] 
145. Hu, P.; Wang, M.; Chen, W.H.; Liu, J.; Chen, L.; Yin, S.T.; Yong, W.; Chen, J.T.; Wang, H.L.; Ruan, D.Y. Quercetin relieves chronic lead exposure-induced impairment of synaptic plasticity in rat dentate gyrus in vivo. Naunyn Schmiedebergs Arch. Pharmacol. 2008, 378, 43-51. [CrossRef] [PubMed]

146. Barcelos, G.R.; Grotto, D.; Serpeloni, J.M.; Angeli, J.P.; Rocha, B.A.; de Oliveira Souza, V.C.; Vicentini, J.T.; Emanuelli, T.; Bastos, J.K.; Antunes, L.M.; et al. Protective properties of quercetin against DNA damage and oxidative stress induced by methylmercury in rats. Arch. Toxicol. 2011, 85, 1151-1157. [CrossRef] [PubMed]

147. Sachdeva, S.; Pant, S.C.; Kushwaha, P.; Bhargava, R.; Flora, S.J. Sodium tungstate induced neurological alterations in rat brain regions and their response to antioxidants. Food Chem. Toxicol. 2015, 82, 64-71. [CrossRef] [PubMed]

148. Sharma, D.R.; Wani, W.Y.; Sunkaria, A.; Kandimalla, R.J.; Verma, D.; Cameotra, S.S.; Gill, K.D. Quercetin protects against chronic aluminum-induced oxidative stress and ensuing biochemical, cholinergic, and neurobehavioral impairments in rats. Neurotox. Res. 2013, 23, 336-357. [CrossRef] [PubMed]

149. Sharma, D.R.; Sunkaria, A.; Wani, W.Y.; Sharma, R.K.; Verma, D.; Priyanka, K.; Bal, A.; Gill, K.D. Quercetin protects against aluminium induced oxidative stress and promotes mitochondrial biogenesis via activation of the PGC-1 $\alpha$ signaling pathway. Neurotoxicology 2015, 51, 116-137. [CrossRef] [PubMed]

150. Sharma, D.R.; Wani, W.Y.; Sunkaria, A.; Kandimalla, R.J.; Sharma, R.K.; Verma, D.; Bal, A.; Gill, K.D. Quercetin attenuates neuronal death against aluminum-induced neurodegeneration in the rat hippocampus. Neuroscience 2016, 324, 163-176. [CrossRef] [PubMed]

151. Bavithra, S.; Selvakumar, K.; Pratheepa Kumari, R.; Krishnamoorthy, G.; Venkataraman, P.; Arunakaran, J. Polychlorinated biphenyl (PCBs)-induced oxidative stress plays a critical role on cerebellar dopaminergic receptor expression: Ameliorative role of quercetin. Neurotox. Res. 2012, 21, 149-159. [CrossRef] [PubMed]

152. Selvakumar, K.; Bavithra, S.; Ganesh, L.; Krishnamoorthy, G.; Venkataraman, P.; Arunakaran, J. Polychlorinated biphenyls induced oxidative stress mediated neurodegeneration in hippocampus and behavioral changes of adult rats: Anxiolytic-like effects of quercetin. Toxicol. Lett. 2013, 222, 45-54. [CrossRef] [PubMed]

153. Beckmann, D.V.; Carvalho, F.B.; Mazzanti, C.M.; Dos Santos, R.P.; Andrades, A.O.; Aiello, G.; Rippilinger, A.; Graca, D.L.; Abdalla, F.H.; Oliveira, L.S.; et al. Neuroprotective role of quercetin in locomotor activities and cholinergic neurotransmission in rats experimentally demyelinated with ethidium bromide. Life Sci. 2014, 103, 79-87. [CrossRef] [PubMed]

154. Nassiri-Asl, M.; Moghbelinejad, S.; Abbasi, E.; Yonesi, F.; Haghighi, M.R.; Lotfizadeh, M.; Bazahang, P. Effects of quercetin on oxidative stress and memory retrieval in kindled rats. Epilepsy Behav. 2013, 28, 151-155. [CrossRef] [PubMed]

155. Datla, K.P.; Christidou, M.; Widmer, W.W.; Rooprai, H.K.; Dexter, D.T. Tissue distribution and neuroprotective effects of Citrus flavonoid tangeretin in a rat model of Parkinson's disease. Neuroreport 2001, 12, 3871-3875. [CrossRef] [PubMed]

156. Shu, Z.P.; Yang, B.Y.; Zhao, H.; Xu, B.Q.; Jiao, W.J.; Wang, Q.H.; Wang, Z.B.; Kuang, H.X. Tangeretin exerts anti-neuroinflammatory effects via NF- $\mathrm{KB}$ modulation in lipopolysaccharide-stimulated microglial cells. Int. Immunopharmacol. 2014, 19, 275-282. [CrossRef] [PubMed]

157. Matsuzaki, K.; Yamakuni, T.; Hashimoto, M.; Haque, A.M.; Shido, O.; Mimaki, Y.; Sashida, Y.; Ohizumi, Y. Nobiletin restoring $\beta$-amyloid-impaired CREB phosphorylation rescues memory deterioration in Alzheimer's disease model rats. Neurosci. Lett. 2006, 400, 230-234. [CrossRef] [PubMed]

158. Onozuka, H.; Nakajima, A.; Matsuzaki, K.; Shin, R.W.; Ogino, K.; Saigusa, D.; Tetsu, N.; Yokosuka, A.; Sashida, Y.; Mimaki, Y.; et al. Nobiletin, a Citrus flavonoid, improves memory impairment and A $\beta$ pathology in a transgenic mouse model of Alzheimer's disease. J. Pharmacol. Exp. Ther. 2008, 326, 739-744. [CrossRef] [PubMed]

159. Nakajima, A.; Aoyama, Y.; Nguyen, T.T.; Shin, E.J.; Kim, H.C.; Yamada, S.; Nakai, T.; Nagai, T.; Yokosuka, A.; Mimaki, Y; et al. Nobiletin, a Citrus flavonoid, ameliorates cognitive impairment, oxidative burden, and hyperphosphorylation of tau in senescence-accelerated mouse. Behav. Brain Res. 2013, 250, 351-360. [CrossRef] [PubMed]

160. Nakajima, A.; Aoyama, Y.; Shin, E.J.; Nam, Y.; Kim, H.C.; Nagai, T.; Yokosuka, A.; Mimaki, Y.; Yokoi, T.; Ohizumi, Y.; et al. Nobiletin, a Citrus flavonoid, improves cognitive impairment and reduces soluble A $\beta$ levels in a triple transgenic mouse model of Alzheimer's disease (3XTg-AD). Behav. Brain Res. 2015, 289, 69-77. [CrossRef] [PubMed] 
161. Yamakuni, T.; Nakajima, A.; Ohizumi, Y. Preventive action of nobiletin, a constituent of AURANTII NOBILIS PERICARPIUM with anti-dementia activity, against amyloid-beta peptide-induced neurotoxicity expression and memory impairment. Yakugaku Zasshi 2010, 130, 517-520. [CrossRef] [PubMed]

162. Jeong, K.H.; Jeon, M.T.; Kim, H.D.; Jung, U.J.; Jang, M.C.; Chu, J.W.; Yang, S.J.; Choi, I.Y.; Choi, M.S.; Kim, S.R. Nobiletin protects dopaminergic neurons in the 1-methyl-4-phenylpyridinium-treated rat model of Parkinson's disease. J. Med. Food 2015, 18, 409-414. [CrossRef] [PubMed]

163. Cui, Y.; Wu, J.; Jung, S.C.; Park, D.B.; Maeng, Y.H.; Hong, J.Y.; Kim, S.J.; Lee, S.R.; Kim, S.J.; Kim, S.J.; et al. Anti-neuroinflammatory activity of nobiletin on suppression of microglial activation. Biol. Pharm. Bull. 2010, 33, 1814-1821. [CrossRef] [PubMed]

164. Yamamoto, Y.; Shioda, N.; Han, F.; Moriguchi, S.; Nakajima, A.; Yokosuka, A.; Mimaki, Y.; Sashida, Y.; Yamakuni, T.; Ohizumi, Y.; et al. Nobiletin improves brain ischemia-induced learning and memory deficits through stimulation of CaMKII and CREB phosphorylation. Brain Res. 2009, 1295, 218-229. [CrossRef] [PubMed]

165. Zhang, L.; Zhang, X.; Zhang, C.; Bai, X.; Zhang, J.; Zhao, X.; Chen, L.; Wang, L.; Zhu, C.; Cui, L.; et al. Nobiletin promotes antioxidant and anti-inflammatory responses and elicits protection against ischemic stroke in vivo. Brain Res. 2016, 1636, 130-141. [CrossRef] [PubMed]

(C) 2016 by the authors; licensee MDPI, Basel, Switzerland. This article is an open access article distributed under the terms and conditions of the Creative Commons Attribution (CC-BY) license (http://creativecommons.org/licenses/by/4.0/). 